\title{
3 Botanical and geotechnical characteristics of blanket peat at three Irish
}

\section{4 bogflows}

9 Alan P. Dykes*

BSc(Hons), PhD, FRGS, FHEA, FGS, CGeol, Associate Professor at Kingston University, Kingston upon Thames, UK

*Corresponding author:

Centre for Engineering, Environment and Society Research, Department of Civil Engineering, Kingston University,

${ }^{\dagger}$ Present address:

10 Crossfield Road, Clacton-on-Sea, CO15 3QT, UK, Tel.: +44 (0)1255 428787,Email: eli71fr@yahoo.fr

Address at the time of this research:

School of Geography and Geology, Kingston University, Kingston upon Thames, UK

7422 words (excluding Figure captions and Tables), 13 Figures, 4 Tables

\section{Abstract}

Systematic investigations of instability and failure of peat covered hillslopes began in the late 1990s and quickly identified the potential importance of botanical controls on the properties and behaviour of the blanket peat involved in the failures. However, attempts to unravel some of these controls did not begin for several years. During 2010-12 investigations of the blanket peat at three relatively recent bogflows in northwest Ireland were done with the aim of 
establishing some form of relationship between botanical or paleoecological characteristics and standard physical and

31 geotechnical properties, assuming the latter to be meaningful but recognising that this may not be the case. In-situ measurements and investigations at all three sites were followed by extensive laboratory characterisation of small core, block and monolith samples.

The botanical composition of the peat could not be fully determined due to the very high degree of decomposition. However, analysis of macrofossils allowed distinct depth-related patterns of several key botanical indicators to be determined. In particular the monocotyledon fragments, dominated by Eriophorum vaginatum, showed distinct and potentially useful distributions throughout the peat profiles. Overall results showed that the basal peat at one of the sites was discernibly different from the other two sites having fewer monocotyledons, fewer fibres, higher dry bulk density and higher saturated hydraulic conductivity. This approach therefore offers a potential basis for developing a means of assessing peat mass characteristics from small auger samples.

\section{Notation}

46 F fibre content

47 Fm fine fibre fraction of the peat (fragment of plant tissue $0.15-1.00 \mathrm{~mm}$ in any dimension)

$48 \mathrm{Rm} \quad$ coarse fibre fraction of the peat (fragment of plant tissue $>1 \mathrm{~mm}$ in any dimension)

49 Ft total fibre fraction of the peat (all fibres $>0.15 \mathrm{~mm}$ in any dimension)

50 Fh humus fraction of the peat (all particles $<0.15 \mathrm{~mm}$ in any dimension)

$51 \quad$ FVS field vane strength

$52 \quad \mathrm{M}_{\mathrm{Ft}} \quad$ mass of the total fibre fraction (g)

$53 \quad \mathrm{M}_{\mathrm{Fh}} \quad$ mass of the humus fraction (g)

$54 \quad \mathrm{M}_{\mathrm{s}} \quad$ mass of oven-dried $\left(105^{\circ} \mathrm{C}\right)$ peat sample - mass of ash (g)

\section{Introduction}

Records of failures of peat bogs go back around 500 years to the collapse of Chat Moss near Manchester, northwest England, in 1526 (Crofton 1902). However, until the late 1990s the occasional studies of isolated examples of peatland failures were largely descriptive with estimates of geometric characteristics and 
occasionally reports of the living plant assemblages present at the time of failure. Systematic investigations began into the stability of blanket peat-covered slopes following significant peat landslides in Northern Ireland (Dykes and Kirk 2001; Kirk 2001) and northern England (Mills 2002; Warburton et al. 2003, 2004). The potential importance of the botanical composition as a controlling factor for the properties and geotechnical behaviour of peat was highlighted earlier by Hobbs (1986), not least because of the widespread adoption by engineers of the von Post scheme for classifying peat deposits (e.g. Landva and Pheeney 1980; Carlsten 1993) which requires the estimation of relative frequencies of fibres and wood/shrub fragments as well as the degree of decomposition of the plant matter (i.e. the humification). The need for research into botanical controls on peat properties was further emphasised with respect to blanket peat instability by Kirk (2001), Dykes (2008a) and O’Kelly (2017) in response to findings from their investigations of physical and geotechnical properties thus far. Indeed, O’Kelly (2017) highlighted the scarcity of published works on the topic and the contradictory findings from the few such studies. The present research (Foteu Madio et al. 2012; Foteu Madio 2013) arose directly from this dearth of previous studies.

The aim of this paper is to examine whether physical and geotechnical properties of Irish blanket peat can be causally associated with measurable botanical characteristics. It does so by presenting and analysing data representing the properties and characteristics of the peat at the sites of three significant bogflows in northwest Ireland, obtained from a combination of field and laboratory investigations. The importance of this study is to provide the basis for more efficient and reliable methods for assessing the stability of peat with respect to planned interventions such as construction of access roads for windfarms or other purposes.

\section{Blanket Bog Failures in Ireland}

The topic of peat mass movements (as distinct from geotechnical engineering of peat) emerged from an esoteric scientific by-way to become a mainstream theme in engineering geology and geomorphology following several major events in late 2003. On 19 September 2003, two entirely independent extreme rainfall events in Co. Mayo, Ireland, and South Shetland, Scotland, triggered multiple failures of peatcovered hillslopes (Dykes and Warburton 2007a, 2008a,b). More significantly for civil engineering, four weeks later the 450,000 $\mathrm{m}^{3}$ Derrybrien Windfarm landslide occurred (Lindsay and Bragg 2005). By that time 
it had already become clear that the Irish blanket bogs were failing in several slightly different ways, giving rise to morphologically distinctive types of failures (Dykes and Warburton 2007b). Most involve shearing of mineral soil beneath the peat ('peaty-debris slides'), shearing at the peat-mineral interface ('peat slides'), or shearing entirely within the basal peat ('bog slides'). 'Peat flows', a term reserved for failures resulting primarily from head-loading, appear to be effectively bearing capacity failures with small areas of shear surface within the basal peat having been observed in the Derrybrien and Ballincollig Hill landslides (Long 2005; Dykes and Jennings 2011).

All of the available evidence relating to 'bog bursts' and 'bogflows' indicate that these failures involved some sort of in-situ liquefaction of the lower or basal peat, with this (semi-)liquid peat slurry then breaking out from beneath a stronger confining acrotelm layer (or from cut faces through the margins of raised bogs) (Dykes and Warburton 2007b). The precise mechanisms of strength loss are unknown. One hypothesis, for characteristics (A P Dykes, unpublished data). A parallel hypothesis is that in some of these failures the lower layer of the peat deposit was always a fluid body, for example if peat grew over a large pond so as to eventually entirely bury it.

In almost all cases of failures of (blanket) peat-covered slopes in Ireland, landslide morphologies and runout characteristics display clear evidence of relatively rapid development of failure associated with very high volumes of rainwater, with eyewitness accounts of some recent events (e.g. the Derrybrien peat flow in 2003, the Croaghan peat slide in 2014) corroborating these interpretations. Warburton et al. (2004) discussed the various hydrological processes giving rise to, or controlling, such failures. It is likely that the peaty-debris slides are triggered by pore pressure effects, in part due to subsurface storm runoff being confined beneath a saturated and effectively impermeable peat cover. Peat slides (interface failures) probably occur for the same reason. Failure within the peat is a more complex issue because of the dual influences of effectively impermeable and normally saturated but weak catotelm peat material and the internal structure of the peat mass (sensu 'rock mass’ considerations) that may experience high turbulent flows and even artesian 
conditions within networks of natural peat pipes and (relict) desiccation cracks (Dykes and Warburton 2007a, 2008a; Gilman and Newson 1980; Holden and Burt 2003). Given the rates of deformation and then movement and the saturated hydraulic conductivity of the intact peat mass through which any shear surface may develop, the focus of our research is on the undrained strength characteristics of basal peat.

\subsection{Study sites}

125 We identified three locally significant bogflows (sensu Dykes and Warburton 2007b) for this study, located 126 within the same region of northwest Ireland: Straduff Townland (hereafter referred to as 'ST'), Slieve 127 Anierin ('SA') and Slieve Rushen ('SR') (Fig. 1). Site and landslide characteristics are summarised in Table 1281 and illustrated in Fig. 2. All were relatively recent, thus limiting the degree of post-failure degradation, and 129 two sites (though not the same landslide at one of these sites) had been investigated previously which 130 provided a cross-check for the peat characterisation results from this study. Furthermore, although the peat at 131 all three sites was generally very similar, one site (Slieve Anierin, below) was noted by Yang and Dykes 132 (2006) to be slightly but nevertheless distinctly different from others including a bogflow at Straduff 133 Townland adjacent to the one used for this study. We anticipated that the results of this new research would 134 also show this.

Table 1. Summary of site details and characteristics of the study bogflows.

\begin{tabular}{|c|c|c|c|c|c|c|c|c|c|c|}
\hline Bogflow & County & Latitude & Longitude & $\begin{array}{c}\text { Elevation } \\
(\mathrm{m})\end{array}$ & $\begin{array}{c}\text { Geology } \\
\text { (Carboniferous) }\end{array}$ & $\begin{array}{c}\text { Geomorphological } \\
\text { Context }\end{array}$ & $\begin{array}{c}\text { Length } \\
\text { (m) }\end{array}$ & $\begin{array}{c}\text { Slope } \\
\left({ }^{\circ}\right)\end{array}$ & $\begin{array}{c}\text { Depth }^{\mathrm{a}} \\
\text { (m) }\end{array}$ & $\begin{array}{l}\text { Volume } \\
\text { (m) }\end{array}$ \\
\hline & & & & & & & & & & \\
\hline ST & Sligo & $54^{\circ} 7.2^{\prime} \mathrm{N}$ & $8^{\circ} 12.9^{\prime} \mathrm{W}$ & 405 & $\begin{array}{l}\text { Lackagh } \\
\text { Sandstone }\end{array}$ & $\begin{array}{l}\text { Escarpment } \\
\text { failure }\end{array}$ & 200 & $\begin{array}{c}5.5 \\
\text { (top) } \\
3 \text { (mid) } \\
6 \\
\text { (lower) } \\
\end{array}$ & 2.5 & 35,000 \\
\hline SR & Cavan & $54^{\circ} 8.9^{\prime} \mathrm{N}$ & $7^{\circ} 38.5^{\prime} \mathrm{W}$ & 390 & $\begin{array}{l}\text { Glenade } \\
\text { Sandstone }\end{array}$ & Basin slope failure & 175 & 5.5 & 2.0 & 20,000 \\
\hline SA & Leitrim & $54^{\circ} 6.3^{\prime} \mathrm{N}$ & $7^{\circ} 58.7^{\prime} \mathrm{W}$ & 440 & $\begin{array}{l}\text { Lackagh } \\
\text { Sandstone }\end{array}$ & $\begin{array}{c}\text { Escarpment } \\
\text { failure }\end{array}$ & 190 & 4 & 2.2 & 22,000 \\
\hline
\end{tabular}


143 Figure 1. Location of the study area in northwest Ireland, showing the distribution of peatlands (after Hammond 1979).

144 The outlined rectangle is enlarged to show the locations of the three bogflows: (left to right) ST = Straduff Townland, SA = Slieve Anierin, SR = Slieve Rushen. Modified from Yang and Dykes (2006).

Figure 2. General views of the three study areas. (A) Straduff Townland bogflow, looking downslope from above the head (July 2010). (B) Slieve Rushen bogflow, looking across at the failed slope from the other side of the peat basin into which its displaced peat flowed (July 2010). (C) Slieve Anierin bogflow from the air (Nov. 1998, photo by APD).

ST, the Straduff Townland landslide, occurred overnight or early morning on 14 August 2008 during very heavy rain. The dominant morphology is that of a bogflow. However, a basal shear surface around $20 \mathrm{~mm}$ above the base of the peat was visible in two small parts of the source area (Dykes 2009; Dykes and Jennings 2011). Although the latter observation corresponds with a 'bogslide' (Dykes and Warburton 2007b), we will refer to this failure as a bogflow. It involved an area of intact blanket peat between the source areas of bogflows dating from 1945 and 1991, leaving narrow strips of minimally displaced peat separating the failures. The physical characteristics of the peat at the 1991 bogflow, just a few metres from the margin of the later failure, were determined by Yang and Dykes (2006). SA (the Slieve Anierin bogflow) is thought to have occurred during 1998, based on its visible condition when first seen from a light aircraft in November 1998 and a conversation with a local resident in 2011. It was described, and the physical characteristics of the peat reported, by Yang and Dykes (2006). The date of SR (the Slieve Rushen bogflow) is uncertain, but the condition of the failure when first inspected in September 2004 was consistent with an age of only a few years, i.e. it most likely occurred during the 1990s (Dykes 2008b).

\section{Methods}

169 The three bogflows were investigated using the same general methodology as previous studies of peat 170 landslides (e.g. Yang and Dykes 2006). All had previously been surveyed in detail by Dykes (2008b, 2009). 
171 The focus for this study was to obtain samples for laboratory testing from a carefully prepared and fully described vertical profile through the full depth of undisturbed in situ peat. Most peat failures leave irregular sub-vertical peat profiles with varying amounts of peat debris covering the lower layers, around several parts of the source area margins. A single study profile (hereafter referred to as the 'study profile' or 'Sampling Point') was selected at each landslide according to the feasibility of creating a clean vertical profile through the full thickness of the peat, i.e. involving the minimum manual excavation of loose peat debris, but ensuring the in-situ peat was undisturbed and not within a few metres of any tension cracks. Safety was ensured by having wide open access to the prepared profile from within the evacuated source area of each landslide, with one person maintaining active watch over the cut face while the other person worked there.

\subsection{Field investigations}

Around each bogflow source area, stratigraphic and topographic surveys were carried out in order to estimate the morphology of the peat deposit and the variability of the peat within it prior to failure. The stratigraphy and maximum depth of the in situ peat was determined on a coarse but regular grid using a $20 \mathrm{~mm}$ diameter gouge auger. Maximum peat depths were measured at additional locations by probing with a metal rod. Peat surface elevations were then surveyed at all the stratigraphy and peat depth measurement points by levelling, with the mineral surface elevations being measured within the landslide source areas and calculated for the peat-covered areas around the source areas from the measured peat depths.

Prior to sampling, a detailed description of the full thickness of the peat at each Sampling Point was recorded according to the von Post (von Post, 1922, as presented by Landva and Pheeney 1980, and Hobbs 1986) and Troels-Smith (Troels-Smith 1955) peat classification schemes. Several sets of samples were obtained from each landslide. Most of the physical/geotechnical samples were obtained from the basal peat at each Sampling Point. Samples were also obtained from the surface and middle peat at the Sampling Point at bogflow ST to provide some indication of depth variations, assuming it to be representative of all three sites. In addition, a Geonor H-60 field shear vane was used to measure the 'field vane strength' (FVS) of the insitu basal peat $\sim 1 \mathrm{~m}$ behind each Sampling Point. For palaeoecological (or simply 'botanical') analyses, monolith samples were extracted that included most of the thickness of the peat profile at each Sampling Point (missing the uppermost part at SR and SA). In addition, $10 \mathrm{~mm}$ cubes of peat were carefully cut from the auger samples from SR at approximately $200 \mathrm{~mm}$ depth intervals (Fig. 5 in Section 4 shows results from this component of the work). Table 2 summarises the samples collected. 
Table 2. Samples extracted from the study bogflows.

\begin{tabular}{|c|c|c|c|c|c|}
\hline $\begin{array}{l}\text { Landslide / } \\
\text { position in } \\
\text { peat profile } \\
\end{array}$ & \begin{tabular}{|l|} 
Physical properties - \\
small cores $50 \mathrm{~mm}$ \\
dia. $\times 51 \mathrm{~mm}$ length \\
\end{tabular} & $\begin{array}{l}\text { Tensile strength }- \\
\text { blocks } 120 \times 120 \times 70 \\
\text { mm }\end{array}$ & \begin{tabular}{|l|} 
Triaxial - \\
$38 \mathrm{~mm}$ dia. \\
cores
\end{tabular} & $\begin{array}{l}\text { Shear strength (direct } \\
\text { shear) - blocks } \\
120 \times 120 \times 70 \mathrm{~mm}\end{array}$ & \begin{tabular}{|l|} 
Monoliths for \\
botanical data \\
$730 \times 100 \times 100 \mathrm{~mm}$ \\
\end{tabular} \\
\hline $\begin{array}{l}\text { ST } \\
\text { see right }\end{array}$ & $\begin{array}{c}6 \text { at } \sim 650 \mathrm{~mm} \text { depth } \\
6 \text { at } \sim 1150 \mathrm{~mm} \text { depth }\end{array}$ & $\begin{array}{c}3 \text { at } 10-80 \mathrm{~mm} \text { depth } \\
3 \text { at } 890-960 \mathrm{~mm} \text { depth }\end{array}$ & -- & $\begin{array}{l}3 \text { at } 10-80 \mathrm{~mm} \text { depth } \\
3 \text { at } 890-960 \mathrm{~mm} \text { depth }\end{array}$ & $\begin{array}{c}1 \text { at } 400-1130 \mathrm{~mm} \\
\text { depth }\end{array}$ \\
\hline $\begin{array}{l}\text { ST } \\
\text { base }^{a}\end{array}$ & 9 & 6 & 6 & 12 & 2 \\
\hline $\begin{array}{l}\text { SA } \\
\text { 300-1030 } \\
\text { mm depth }\end{array}$ & -- & -- & -- & -- & 1 \\
\hline $\begin{array}{l}\text { SA } \\
\text { base }^{\text {a }}\end{array}$ & 9 & 6 & 6 & 12 & 2 \\
\hline $\begin{array}{l}\text { SR } \\
100-830 \\
\text { mm depth } \\
\end{array}$ & -- & -- & -- & -- & 1 \\
\hline $\begin{array}{l}\text { SR } \\
\text { base }^{b}\end{array}$ & 9 & 6 & 6 & 12 & 2 \\
\hline
\end{tabular}

204 a 1600-1700 mm depth below the surface of the peat, 970-1700 mm depth for the lower monoliths

b 1900-2000 mm depth, 1270-2000 mm depth for the lower monoliths

\subsection{Laboratory testing}

209 Some physical properties of peat can give a rough indication of the state or condition of the peat (Hobbs,

210 1986). Therefore, standard methods were used to determine the water content and bulk density (oven-drying

211 for $24 \mathrm{~h}$ at $105^{\circ} \mathrm{C}$ : O’Kelly 2017), loss on ignition $\left(550^{\circ} \mathrm{C}\right.$ for 3h: Skempton and Petley 1970; Andrejko et al.

212 1983; Jarrett 1983; Hobbs 1986) and saturated hydraulic conductivity ('constant head' method) to provide

213 reference details for correlation with the results of the botanical and geotechnical analyses. There has been

214 some debate in recent years regarding the appropriate drying temperature for water content determination,

215 including evidence of the possibility of charring of the peat at temperatures higher than $80-90^{\circ} \mathrm{C}\left(\mathrm{O}^{\prime} \mathrm{Kelly}\right.$

216 2014). Further, O’Kelly (2014) found experimentally that the possible additional loss of mass due to charring

217 is negligible compared with the mass of any retained water due to incomplete drying, particularly

218 intracellular water within peat fibres that may constitute a significant proportions of the peat mass (Foteu

219 Madio 2013), and so recommended following the standard specification for mineral soils of $105^{\circ} \mathrm{C}$ as used

220 by many previous workers including Skempton and Petley (1970) and Hobbs (1986). We adopted the latter

221 approach for the demonstrated reasons of standardisation and comparability of results. 
223 For the constant head method we used a laboratory permeameter arrangement as described by, for example, 224 Klute and Dirksen (1986) or Head (1994). Undisturbed core samples collected in thin-walled tubes $50 \mathrm{~mm}$ 225 long $\times 50.5 \mathrm{~mm}$ diameter were trimmed to size, saturated in tap water and mounted vertically to form a 226 permeameter maintaining a constant head of $0.15 \mathrm{~m}$ of water on the top of the sample. Water that passed 227 through the sample was collected underneath and measured. The constant head saturated hydraulic 228 conductivity was calculated according to Darcy’s Law.

230 The proportion of intracellular and interparticle water depends upon the structure and morphology of the 231 various plants present and on the degree of humification of peat (Hobbs 1986). Microfossils, including pollen 232 grains, may not represent the original in situ vegetation because they are small enough to be transported by 233 the wind, possibly over long distances. Therefore we investigated the fibres, macrofossil content and the 234 degree of humification of the peat. The latter influences the water holding capacity, pore sizes and fibre 235 quantities and properties, all of which could influence the peat strength. The fibres and macrofossils are 236 likely to directly affect the strength and other geotechnical properties.

\subsubsection{Humification}

239 Humification was quantitatively determined in the laboratory followed a modified version of the Bahnson 240 colorimetric method (Aaby and Tauber 1974; Blackford and Chambers 1993; Chambers et al. 1997).

241 Subsamples taken contiguously at every $10 \mathrm{~mm}$ from the monoliths were tested. The measurements were 242 obtained using a Hatch 2500 spectrometer set up at $540 \mathrm{~nm}$. Results are expressed as 'raw' percentages of 243 light transmission through the diluted peat solution. The more light passes through the peat solution, the less 244 humified the sample.

\subsubsection{Fibres}

247 The fibre content (F) is an important characteristic that influences peat stability (Long and Jennings, 2006) as

248 it affects the peat structure and its strength properties. To explore this effect, we firstly re-defined the 249 different fractions as follows: (i) a 'fine fibre' (Fm) is a fragment or piece of plant tissue between 0.15 and $2501.00 \mathrm{~mm}$ in any dimension including length; and (ii) a 'coarse fibre' (Rm) is a fragment or piece of plant 
tissue $>1 \mathrm{~mm}$ in any dimension. In line with the ASTM's (2008) standard for determining the fibre content of peat, the 'total fibre fraction' (Ft) is been defined as all fibres $\geq 0.15 \mathrm{~mm}$ in any dimension. The humus fraction (Fh) is defined as all particles $<0.15 \mathrm{~mm}$ in any dimension. We recognise that it is difficult to determine a specific shape of some fibres and that, depending on the orientation of the fibre, any dimension of a fibre or particle of a particular shape (e.g. elongated fibres) can prevent it passing through a hole in the sieve, so further refinements to this methodology are likely to be needed in the future.

The Fm and Rm fibre fractions were estimated in the field based on the von Post system as presented by Hobbs (1986, p.79): Fine fibres (Fm) are 'fibres and stems smaller than $1 \mathrm{~mm}$ in diameter or width' and coarse fibres (Rm) are 'fibres, stems, and rootlets greater than $1 \mathrm{~mm}$ in diameter or width'. To both of these definitions we added 'or any plant particle' and took the size boundary as ' $<$ or $>1 \mathrm{~mm}$ in all directions'. The von Post scheme uses a four point scheme from 0 'nil' to 3 'high content' but without a microscope it is difficult to be certain that there are no fragments of fibre present. Consequently we removed ' 0 ' and assessed the quantity according to a five point scale: $1=$ very low content (VL), $2=$ low content $(\mathrm{L}), 3=$ medium content $(\mathrm{M}), 4=$ high content $(\mathrm{H})$ and 5 = very high content $(\mathrm{VH})$. All of the other fractions defined above were determined in the laboratory and recorded using a similar 5-point scheme:

For the laboratory determinations, duplicate subsamples of known masses were taken every $70 \mathrm{~mm}$ from along the lowest monolith sample from each site. These were analysed differently in order to separate the peat into different fractions, the initial part of the procedure following ASTM (2008) but with a much smaller initial sample mass. Thus the fibre contents of the lowest $0.7 \mathrm{~m}$ of the peat profile at each landslide's 
Sampling Point were fully quantified. The first subsample was soaked in a dispersing agent (5\% sodium hexametaphosphate) for approximately 15 hours and then the peat was gently washed through a $0.15 \mathrm{~mm}$ mesh size sieve using tap water. The fibrous material retained on the sieve was washed through a further 1 $\mathrm{mm}$ sieve and the fine fraction that passed through was collected. The fibres retained on the $1 \mathrm{~mm}$ sieve comprised the coarse fraction. Both fractions were oven-dried at $105^{\circ} \mathrm{C}$ until constant masses were achieved. The masses of fine and coarse fibres were combined to obtain the total mass of fibres. The mass of humus was obtained from the difference between the mass of total fibres and the initial dry mass of peat determined from the second subsample. The second subsample was dried at $105^{\circ} \mathrm{C}$ for $24 \mathrm{~h}$ and the mass ratio of dry to wet peat determined. The duplicate peat samples had slightly different masses and assuming that their respective mass ratios of dry to 'field wet' peat were equal, the corresponding initial mass of the sample used for fibre content testing was established. The fibre (Ft) and humus (Fh) fractions (without any mineral matter) were then expressed as percentages of the initial dry mass $\left(\mathrm{M}_{\mathrm{s}}\right)$ as follows:

$$
\begin{aligned}
& \mathrm{Ft}=\left(\mathrm{M}_{\mathrm{Ft}} / \mathrm{M}_{\mathrm{s}}\right) \times 100 \\
& \mathrm{Fh}=\left(\mathrm{M}_{\mathrm{Fh}} / \mathrm{M}_{\mathrm{s}}\right) \times 100
\end{aligned}
$$

where $\mathrm{M}_{\mathrm{Ft}}$ and $\mathrm{M}_{\mathrm{Fh}}$ are the masses (g) of the fibre and humus fractions, respectively, after drying at $105^{\circ} \mathrm{C}$ to constant mass then subtracting the mass of ash, and $\mathrm{M}_{\mathrm{s}}$ is the mass (g) of the initial peat sample after drying at $105^{\circ} \mathrm{C}$ to constant mass less the mass of ash.

\subsubsection{Macrofossils}

The heterogeneity of peat is due to the variability of factors and environmental gradients that influence its initiation and development (Moore, 1984; Charman, 2002). The original plant composition of peat influences its structure and is assumed to affect its geotechnical properties. We used macrofossil analysis to assess these botanical factors. $10 \mathrm{~mm}$ cubes of peat were obtained from the along the length of each monolith sample, with 40-80 mm separation except within the basal peat where the cubic subsamples were contiguous. Analysis was undertaken using the 'Quadrat and Leaf Count Macrofossil Analysis technique' (QLCMA) developed at the Southampton Palaeoecology Laboratory (Barber et al. 1994). The method estimates the percentage coverage of all macrofossil types with the aid of a $10 \times 10$ grid graticule in the eyepiece of a stereomicroscope. Monocotyledon epidermis tissues and Sphagnum branch leaves were examined further at a magnification of $\times 400$ under transmitted light. Daniels and Eddy (1990) (for 
Sphagnum), Smith (2004) (for other bryophytes), Grosse-Brauckmann (1972) and Katz et al. (1977) (for

vascular plants) were used to identify the remains.

The additional small cubic samples obtained from SR were further investigated using the method developed by Walker and Walker (1961), in which on a scale of 0 to 5, 0 indicates absence and 5 indicates that the sample consisted largely of a particular macrofossil. This was done to check that peat at the Sampling Point was representative of the entire blanket bog.

\subsubsection{Shear strength}

318 The mechanism of failure of in-situ peat in natural landslides is uncertain and indeed there may be different mechanisms operating in different contexts. Examples of these are outlined in Section 2. Our tests focused on undrained shear strength because of the documented rapid development of failures compared with the measured very low permeability of Irish catotelm peat (e.g. $10^{-6}$ to $10^{-9} \mathrm{~m} \mathrm{~s}^{-1}$ : see Section 4.2.1). We used a direct shear apparatus with a $100 \mathrm{~mm} \times 100 \mathrm{~mm}$ shearbox to try to obtain reproducible values of shear strength using normal stresses representing in-situ conditions, i.e. typically less than $5 \mathrm{kPa}$ (after Dykes 2008a). Samples were sheared at normal stresses of 0.7, 1.2, 1.7, 2.2, 3.2, 4.2 and $5.6 \mathrm{kPa}$ using the method outlined by Dykes (2008a), i.e. no pre-consolidation, but with a slightly higher shear rate of $1 \mathrm{~mm} \mathrm{~min}^{-1}$ $\left(2 \times 10^{-5} \mathrm{~m} \mathrm{~s}^{-1}\right)$ to represent moderate failure (IUGS, 1995) with the associated likelihood of undrained shearing effects.

The triaxial tests were intended to give an indication of the undrained shear strength and associated stressstrain behaviour of the peat by means of rapid unconsolidated-undrained tests on standard $38 \mathrm{~mm}$ diameter $\times$ $76 \mathrm{~mm}$ high samples (carried out according to Head (1994)) at a range of cell pressures at the lowest end of what was possible with the available equipment, i.e. 50, 100 and $200 \mathrm{kPa}$. To minimise membrane effects we used thinner membranes, samples were allowed to saturate before the axial load was applied at $1 \mathrm{~mm} \mathrm{~min}^{-1}$ as for the direct shear tests. After each test, the sample was visually inspected to assess the failure mechanism or any other deformation. The bi-linear correction of the deviator stress due to membrane stiffness was not applied to the results because although the effect may be significant, (i) there is no consensus on appropriate corrections given complex peat-membrane interactions, and (ii) this was primarily 
a comparative study that was not necessarily expected to determine the exact value of the shear strength of peat.

\subsubsection{Tensile strength}

342 The tensile strength of block samples of undisturbed peat was measured using the equipment (Fig. 3C) and 343 procedure described by Dykes (2008c). This involved applying a tensile load, in $100 \mathrm{~g}$ increments, to half of 344 the cross-sectional area of each $100 \times 100 \mathrm{~mm}$ test sample by means of five $10 \mathrm{~mm}$ wide steel fingers (Fig. 345 3A), the tensile resistance being provided by the four $12.5 \mathrm{~mm}$ wide strips of peat between the fingers (Fig. 3B). Tensile stress and strain were recorded $30 \mathrm{~s}$ after the application of each load increment until the sample failed. Although results obtained using this method have been found to be reproducible and consistent, two key limitations are recognised: (i) the apparatus does not allow a vertical load to be placed on the sample to replicate the condition of the basal peat in-situ; and (ii) significant sample disturbance may occur during installation due to large fibres or woody fragments (Dykes 2008c).

\section{$<$ FIGURE $3>$}

354 Figure 3. Measuring the tensile strength of the peat: (A) the two sets of steel 'fingers' that are pushed through the centre of a cut block of undisturbed peat $100 \mathrm{~mm}$ high $\times 100 \mathrm{~mm}$ wide and 40-60 mm thick; (B) one half of a sample following tensile failure, still adhering to one set of 'fingers'; (C) the testing apparatus, showing: centre - the 'fingers' assembly installed (without a sample); right - the force proving ring; lower far left - the hanger for applying the weights that apply the load just visible beside the end of the cupboards. Details of the design and development of this apparatus are provided in Dykes (2008c).

\section{Results}

\subsection{Field descriptions of the peat}

365 The peat at the three landslides showed remarkably little variability in terms of structure and macrofossil 366 content. Four major stratigraphic units were identified at each site. The first unit (starting at the top), 
including the living roots near the surface, comprised slightly humified peat, with each unit below being progressively more humified and the fourth unit at the base having highly humified and/or greasy peat, sometimes with bitumen or sludge like patches (Table 3; e.g. Fig. 4). The identifiable plant material in the peat was predominantly monocotyledon ('monocot') remains ('Turfa herbacea' in the Troels-Smith scheme) including undifferentiated roots, stems and leaves (Fig. 5). This general lack of variation between (Table 3) and within (Fig. 5) sites allowed us to consider one Sampling Point as being broadly representative of each landslide site.

$<$ FIGURE $4>$

Figure 4. Peat stratigraphy across the slope above the head of the Slieve Rushen bogflow. This linear transect was located 7.5 m upslope of the source area head at the closest point. Modified from Foteu Madio (2013).

Figure 5. Results of macrofossil analyses of samples obtained from across the Slieve Rushen bogflow. Labels A1, A5, etc. refer to sampling positions: A1 to A9 are shown in Fig. 5; E1/E3 and E4/E7 are located either side of the downslope extent of the source area. The materials found at each position are from, and in the same order as, this list: Charcoal (0.5-1 mm); Charcoal (less than $0.5 \mathrm{~mm}$ ); Ericales; Eriophorum vaginatum; Monocot fragments (Monocot leaves at E4), Roots; Sphagnum; Unidentified organic matter. Source: Foteu Madio (2013).

\subsection{Physical and mechanical properties of the peat}

\subsubsection{Geotechnical characteristics}

The basic physical properties of the peat at the three landslides are summarised in Table 4. These are broadly consistent with previous results obtained from Straduff Townland (the 1997 bogflow adjacent to ST) and SA by Yang and Dykes (2006). Uncorrected field shear vane readings from depths between 1.25 and $2.00 \mathrm{~m}$ were between 6.6 and $14.0 \mathrm{kPa}$ at all sites and there were insufficient results from which to identify any 
patterns in the data. No corrections were applied because this was intended as a comparative study and the shear vane is known to be inappropriate for the determination of the undrained strength of peat due to the effects of fibres, although it can be used to identify patterns of peat strength variation with depth.

Results from the experimental low-stress direct shear tests (without consolidation prior to shearing) are shown in Fig. 6. These are consistent with results obtained from basal peat at another landslide in northwestern Ireland (identified as ‘E6’ by Kirk (2001): Dykes 2008a). The surface peat at ST clearly demonstrates a higher strength due to the greater density, and probably strength, of less humified fibres. approximations in the normal stress range 2-5 kPa would all give cohesion intercepts of 1-4 kPa (Fig. 6). If the peat was overconsolidated by up to $10-15 \mathrm{kPa}$ as seems to be the general case (O’Kelly 2017), such low shear stress values within this range of applied normal loads should not be expected.

Results from the unconsolidated-undrained triaxial tests similarly demonstrate the inherently low shear strength of the basal peat with all three sites in the range 1.5-2.5 kPa (Fig. 7). Slight variations in the diameters of the Mohr's circles arise from the heterogeneity of the peat mass, as also observed in raised bog peat by Hanrahan (1954), but may also result from gas in the peat causing variations in pore water pressures within the samples. Hanrahan (1954) found that the gas content of Irish Sphagnum peat may be considerably in excess of $5 \%$ of the volume and that significant volumes of gases such as sulphuretted and phosphorated hydrogen (phosphine), as well as methane, could be emitted during construction involving the compression of peat. Therefore the possibility of gas affecting both permeability and pore pressures must be allowed for

Fig. 8 shows the tensile strengths obtained from this and previous studies using the same methodology (Dykes 2008c). The tensile strengths of the basal peat at the three landslides in this study are all less than 3 $421 \mathrm{kPa}$ except where locally reinforced by matted woody fragments. With the exception of two outliers, which arose from the respective samples containing significant fragments of decomposing roots or woody stems, there is an apparent trend of reducing tensile strength with depth. Although this trend arises from combined results from several locations in Ireland, the similarities of all other measured peat properties between all of 
these sites (Dykes 2008c; Dykes and Warburton 2008a; Dykes and Jennings 2011) means that this general trend is probably real. At individual sites it is possible that such a trend of decreasing tensile strength with depth may not always be found, although there are insufficient relevant data to be able to comment further.

Helenelund (1967) suggested that the fibre contents, types and orientations - which depend on the morphology and the mode of growth of the original plant assemblage that formed the peat - may have major influences on the tensile strength. The macrofossil analyses of peats from our study sites revealed remains of sedges, the degree of humification of which increase with depth. In such monocotyledon peat, fibres are the remains of vascular bundles formed from the root systems that grow perpendicularly to the ground surface. The resulting tensile strength will therefore be related to the resisting force produced by the fibres, the frequency of which decreases with depth and is inversely proportional to the degree of humification. The tensile strength results obtained by Helenelund (1967) from Sphagnum bog peat, which has very few fibres, are comparable with the lowest of our results, showing that the monocotyledon peats at our sites generally have higher tensile strengths than Sphagnum bog peat. Due to the effect of compression during the accumulation of the peats, some fibres that were originally distributed vertically through the peat become squashed progressively into a horizontal alignment as pressure increases. The degree of inclination of these fibres toward the horizontal plane should therefore also increase with depth. The tensile strength values presented in this study were measured in a horizontal plane, intended to represent the effect of the peat mass pulling apart above a basal (shear?) failure zone. The effect of fibre orientation should be to increase the tensile strength with depth since horizontal breaking up of a failing peat mass is resisted by sometimes significant lengths of fibres adhering to amorphous colloidal matrix material. However, the role of living and minimally decomposed roots within the near-surface acrotelm layer combined with the very high degree of humification below the acrotelm appears to entirely override the fibre orientation effect.

\section{$<$ FIGURE $6>$}

Figure 6. Results from experimental low-stress direct shear tests of basal peat from all three landslides and from around 10-60 mm depth at Straduff Townland. Previous results from bog slide 'E6' at Cuilcagh Mountain, Co. Cavan, obtained using the same methodology, are also shown. Modified from Foteu Madio et al. (2012), after Dykes (2008a). 
$<$ FIGURE $7>$

Figure 7. Mohr's Circles (total stresses) obtained from unconsolidated-undrained triaxial tests on peat samples from the three landslides: (A) ST - Straduff Townland; (B) SR - Slieve Rushen; (C) SA - Slieve Anierin. Source: Foteu Madio (2013).

Figure 8. Tensile strength results obtained from the three landslides in this study and from previous studies using the 464 same methodology. MHA-00s refers to the Maghera bogflow, Co. Galway; SDF-08 is bogflow ST in this study; BHW46508 is the Ballincollig Hill peat flow, Co. Kerry; DCM-03 is the collective reference for the 40 landslides that occurred 466 on Dooncarton Mountain, Co. Mayo on 19 September 2003, the results here being obtained from peat slide 'SE5'. 467 Modified from Foteu Madio (2013).

\subsubsection{Humification and fibres}

472 The results of the quantitative determination of humification, recorded as the 'raw' percentage of light 473 transmission through the peat, showed no significant differences between the mean values for the three sites. 474 However, only the results from ST showed a clear reduction in light transmission (i.e. increase in degree of 475 humification) with depth (Fig. 9). 
Table 3. Summary description of the peat at each landslide Sampling Point (Foteu Madio 2013). The four major stratigraphic units are separated by the solid lines of the Table.

\begin{tabular}{|c|c|}
\hline Depth (m) & Peat profile description at ST \\
\hline $0.00-0.40$ & $\begin{array}{l}\text { Light brown fibrous peat, slightly humified, mainly monocotyledon fine fibres and low amorphous } \\
\text { material, moderate horizontal tensile strength. }\end{array}$ \\
\hline $0.40-0.78$ & $\begin{array}{l}\text { Black and moderately humified, mainly monocotyledon fine fibre peat and moderate amorphous } \\
\text { material, moderate horizontal tensile strength. }\end{array}$ \\
\hline $0.78-1.22$ & $\begin{array}{l}\text { Light brown with dark patches, very weak and moderately humified peat. Monocotyledon fine fibre } \\
\text { limited. Low horizontal tensile strength. }\end{array}$ \\
\hline $1.22-1.60$ & $\begin{array}{l}\text { Brown, moderately to strongly humified peat. Monocotyledon fine fibre present. Low horizontal } \\
\text { tensile strength. }\end{array}$ \\
\hline $1.60-1.80$ & $\begin{array}{l}\text { Dark grey, greasy, highly humified and amorphous peat. Rare and very fine monocotyledon } \\
\text { fragments. Low to zero horizontal tensile strength. }\end{array}$ \\
\hline$>1.80$ & Sandstone in clay matrix, 5YR 3/1on the Munsell soil colour chart. \\
\hline Depth (m) & Peat profile description at $\mathrm{SR}^{1}$ \\
\hline $0.00-0.15$ & $\begin{array}{l}\text { Brown fibrous peat with moderately humified, mainly monocotyledon fine fibres and low amorphous } \\
\text { material, moderate horizontal tensile strength. }\end{array}$ \\
\hline $0.15-0.36$ & $\begin{array}{l}\text { Brown, less fibrous peat with moderately humified, mainly monocotyledon fine fibre peat and } \\
\text { moderate amorphous material, moderate horizontal tensile strength. }\end{array}$ \\
\hline $0.36-0.58$ & Dark brown humified peat with monocotyledon fragments. Low horizontal tensile strength. \\
\hline $0.58-0.88$ & Dark brown decomposing peat with monocotyledon fragments. Low horizontal tensile strength. \\
\hline $0.88-1.58$ & $\begin{array}{l}\text { Dark grey, highly humified and amorphous peat. Very fine monocotyledon fragments. Low to zero } \\
\text { horizontal tensile strength. }\end{array}$ \\
\hline $1.58-1.64$ & $\begin{array}{l}\text { Dark grey, greasy, highly humified and amorphous peat. Very fine monocotyledon fragments. Low to } \\
\text { zero horizontal tensile strength. }\end{array}$ \\
\hline$>1.64$ & Sandstone in clay matrix, 5YR 3/1 on the Munsell soil colour chart. \\
\hline Depth (m) & Peat profile description at SA \\
\hline $0.00-0.76$ & $\begin{array}{l}\text { Dark fibrous peat, slightly humified, mainly monocotyledon fine fibres, low amorphous material and } \\
\text { moderate horizontal tensile strength. }\end{array}$ \\
\hline $0.76-1.56$ & $\begin{array}{l}\text { Light brown less fibrous peat with moderately humified, mainly monocotyledon fine fibre peat, } \\
\text { moderate amorphous material and moderate horizontal tensile strength. }\end{array}$ \\
\hline $1.56-1.76$ & Black humified peat with monocotyledon fragments. Low horizontal tensile strength. \\
\hline $1.76-1.78$ & $\begin{array}{l}\text { Dark grey, greasy, highly humified and amorphous peat. Very fine monocotyledon fragments. Low to } \\
\text { zero horizontal tensile strength. }\end{array}$ \\
\hline$>1.78$ & Sandstone in clay matrix, 5YR 3/1on the Munsell soil colour chart. \\
\hline
\end{tabular}

$486 \quad{ }^{1}$ Recorded in July 2010 prior to the moorland fire. 
Table 4. Summary of physical properties of peat at the three landslides, including previous data from Yang and Dykes

\begin{tabular}{|c|c|c|c|c|c|}
\hline & $\begin{array}{l}\text { Water content }{ }^{\mathrm{a}, \mathrm{b}} \\
\text { (\% mass fraction) }\end{array}$ & $\begin{array}{l}\text { Loss on Ignition }{ }^{c} \\
\text { (\%) }\end{array}$ & $\begin{array}{l}\text { Saturated bulk } \\
\text { density } \\
\left(\mathrm{Mg} \mathrm{m}^{-3}\right)\end{array}$ & $\begin{array}{l}\text { Dry bulk density } \\
\left(\mathrm{Mg} \mathrm{m}^{-3}\right)\end{array}$ & $\begin{array}{l}\text { Saturated } \\
\text { hydraulic } \\
\text { conductivity h,i } \\
\left(\mathrm{m} \mathrm{s}^{-1}\right)\end{array}$ \\
\hline ST & $\begin{array}{l}700-900 \\
* 620-860 \\
\end{array}$ & $\begin{array}{l}94.5-95.6 \\
* 97.8-98.8 \\
\end{array}$ & $\begin{array}{l}1.00^{\mathrm{f}} \\
* 1.06\end{array}$ & $\begin{array}{l}0.10-0.20 \\
* 0.13 \\
\end{array}$ & $\begin{array}{l}10^{-9} \text { to } 10^{-8} \\
*<10^{-11}\end{array}$ \\
\hline SR & \begin{tabular}{|l|}
$600-700$ \\
\end{tabular} & $94.6-97.2^{\mathrm{d}}$ & 1.00 & \begin{tabular}{|l|}
$0.10-0.20$ \\
\end{tabular} & $10^{-9}$ to $10^{-6}$ \\
\hline SA & $\begin{array}{l}600-700 \\
* 600-740\end{array}$ & $\begin{array}{l}95.0 \\
* 97.7-98.5\end{array}$ & $\begin{array}{l}1.00 \\
* 1.05\end{array}$ & $\begin{array}{l}0.20^{\mathrm{g}} \\
* 0.15\end{array}$ & $\begin{array}{l}10^{-8} \text { to } 10^{-6} \\
*<10^{-11}\end{array}$ \\
\hline
\end{tabular}

497 a There was negligible difference between field-wet and saturated water contents at all sites

498 b Indicative ranges of mean values from 256-319 samples per site

$499{ }^{\mathrm{C}}$ Indicative ranges of mean values from 123-196 samples per site

$500{ }^{\mathrm{d}}$ The basal peat at Slieve Rushen was noticeably higher in organic matter than any other sampled peat

501 e Mean values from 20-26 samples per site

$502{ }^{\mathrm{f}}$ The basal peat at Straduff Townland was noticeably higher $\left(\sim 1.10 \mathrm{Mg} \mathrm{m}^{-3}\right)$ than any other sampled peat

$503 \quad{ }^{\mathrm{g}}$ The peat at Slieve Anierin had higher dry bulk densities throughout its depth

504 h Indicative ranges of mean values from 19-26 samples per site, obtained using a 'constant head' method

$505{ }^{i}$ Results obtained using a 'falling head' method were consistently $10^{2}-10^{3} \mathrm{~m} \mathrm{~s}^{-1}$ higher than the respective 'constant 506 head' values

509 The mean 'total fibre fraction’ (Ft) of the lowest $0.7 \mathrm{~m}$ of the peat profile at each landslide Sampling Point, 510 based on 70 depth-consecutive measurements per site, was $68 \%$ at ST, $71 \%$ at SR and 56\% at SA. As Fig. 10 511 shows, the latter appears to indicate a small but consistent difference from the other two, having slightly 512 fewer coarse fibres throughout the sampled depth range. At all three sites there is a general trend of reducing coarse fibre content with depth but the fine fibre content seems to increase slightly towards the base of SR.

517 Figure 9. ‘Raw’ percentage of light transmission at the Straduff Townland bogflow (ST).

520 Figure 10. Depth variations of fibre contents throughout the lower half of the peat profile at each landslide: (A)

521 Straduff Townland, (B) Slieve Rushen, (C) Slieve Anierin. Source: Foteu Madio (2013). 


\subsection{Peat stratigraphy according to macrofossil results}

525 The blanket bog at the Sampling Point at each landslide mostly comprised the remains of monocotyledon 526 plants, particularly E. vaginatum (Fig. 11). Monocotyledon contents were lowest within the basal peat zones 527 (as defined by cluster analysis) and, at ST, immediately above the basal zone.

Figure 11. Macrofossil content of the peat monolith from the three landslides: (a) ST, (b) SR, (c) SA. Parameter values are raw counts for charcoal and $E$. vaginatum spindles, otherwise percentages. The figure shows the dendrogram produced from unconstrained incremental sum square cluster analysis of strata analysed. Dashed lines separate clusters corresponding to zones in the diagram. Source: Foteu Madio (2013).

\subsection{Comparing botanical and geotechnical characteristics}

538 The results were examined in order to identify any statistical associations (using Pearson's ' $r$ ' correlation coefficient) between physical/geotechnical parameters, and then between geotechnical characteristics and botanical results, that may have physical explanations potentially exploitable for predictive purposes. In this study, only significant $(\mathrm{p}<0.05)$ correlations with $|\mathrm{r}|>0.7$ at all three landslides were interpreted as possibly

542 indicating a causal relationship because the study was based on a single monolith per study site.

543 Furthermore, the full depth of the peat at each site was not analysed for most of the parameters investigated.

544 The only significant associations with $|r|>0.7$ that were found between physical/geotechnical parameters at 545 all three sites were between: (i) the humus fraction, Fh, and the total fibre content, Ft (Fig. 12A); (ii) the total 546 fibre content, Ft, and the coarse fibre fraction, Rm (Fig. 12B); (iii) the humus fraction, Fh, and the coarse 547 fibre fraction, Rm; and (iv) the coarse fibre fraction, $\mathrm{Rm}$ - and therefore also the total fibre content and the 548 humus fraction - and the field water content (Fig. 12C). 
Figs. 12D and 12E show the only consistently high correlations $(\mathrm{p}<0.05)$ between macrofossil data and physical/geotechnical properties of peat, i.e. between: (i) the total fibre content and the proportion of monocot fragments; and (ii) the von Post degree of humification and the percentage of unidentified organic matter. This may arise from the QLCMA method used for macrofossil analyses probably being more appropriate for Sphagnum peat with small leaves that can be easily counted, compared with monocotyledon peat with larger original plant fragments. The general lack of strong or consistent associations correlations between the physical/geotechnical and botanical parameters at the three landslides suggests that these physical properties cannot be used as indicators of peat mass structure and, thus, of potential peat instability. However, the method used to quantify the fibre contents (Section 3.2.2, above) may be useful for investigating relationships between the structural properties of failed Irish blanket peats in order to classify peat for stability assessments.

The macrofossil analyses at the three landslides showed that the original plant assemblage was predominantly monocotyledons, especially Eriophorum vaginatum. Therefore, the undrained strengths obtained at the three landslides were plotted against the other properties (e.g. coarse fibre content in Fig. 12F) in order to investigate any possible relationship that may exist. The statistical analyses revealed no significant correlation coefficients $(\mathrm{p}<0.05)$.

Fig. 13 shows the thickness of a weak basal layer at each site identified by cluster analyses of the results (e.g. Fig. 11). If all three landslides failed in a similar manner (i.e. by initial basal shearing), then it appears that field observations of shear surfaces within a few tens of mm above the peat-mineral interface can be explained in terms of formation of a failure zone (a) within the weakest layer of the peat profile, and (b) at the lowest elevation within that weakest layer giving a continuous plane above the level of any large stones or woody remnants that would resist shearing within the basal peat. The mean thickness of this layer based on cluster analyses of the data (e.g. Fig. 11) is around $170 \mathrm{~mm}$, but this is clearly overestimated because of 
580 Figure 12. Correlations between physical/geotechnical parameters and between botanical characteristics of the peat. (A)

581 Total fibre content vs. humus fraction. (B) Total fibre content vs. coarse fibre fraction. (C) Coarse fibre fraction vs. field 582 water content. (D) Monocot fragments vs. total fibre content. (E) Unidentified organic matter vs. von Post humification. 583 (F) Undrained shear strength (including 'field vane strength') vs. total fibre content. In (A) to (E), solid line = ST, long 584 dashed line $=$ SR and the thin broken line = SA. After Foteu Madio (2013).

588 Figure 13. Variation of mean thickness of basal peat depths according to specific physical properties at all three 589 landslides.

\section{Discussion}

594 The three sites investigated for this study were remarkably similar in terms of the characteristics of their blanket peat. Slieve Anierin had a lower fraction of identifiable monocot fragments and a correspondingly higher fraction of unidentified organic matter, but this may simply reflect greater decomposition of the same plants rather than being evidence of different constituents. The smaller proportion of coarse fibres throughout the peat at this site, and particularly towards the base, supports the interpretation of more advanced decomposition. However, the higher dry bulk density and slightly higher saturated hydraulic conductivities (Table 4) perhaps indicate a very slightly different composition. One tensile strength measurement at this site was significantly out of line with the others (Fig. 8) due to a high density of woody remains within one test sample, but the other measures of shear strength were entirely consistent with the other two sites. Therefore we suggest that this site has essentially the same palaeoenvironmental history of peat accumulation as the others. Furthermore, the similarity between these results and some obtained from other landslide sites throughout northwestern and western Ireland and Northern Ireland (e.g. Kirk 2001; Yang and Dykes 2006; Dykes 2008c; Dykes and Warburton 2008a; Dykes and Jennings 2011) and indeed eastern Ireland (e.g. 
Boylan and Long 2010) strongly suggests that the general geotechnical characteristics of upland blanket peat throughout the island of Ireland are very similar everywhere.

Much of the present vegetation of Ireland's blanket bogs is dominated by sedges (e.g. E. vaginatum),

611 heathers (Ericacae, including Calluna vulgaris) and some Sphagnum and other mosses. These are all 612 represented in the analyses, with the sedges dominating the identifiable macrofossils (Fig. 10). In many 613 places there are the remains of trees at the base of the peat, which act like fragments of weathered bedrock to 614 resist movement of the peat over the in situ ground. However, at these three sites, separated by up to $20 \mathrm{~km}$, there is a weak basal layer around $150 \mathrm{~mm}$ thick that can be clearly distinguished from the peat above on the basis of the properties measured for this study. Intriguingly, a higher proportion of the macrofossils can be identified as monocot fragments in this layer, which somewhat contradicts the idea of greater decomposition.

618 On the other hand, fibre contents reduce sharply towards this basal layer (Fig. 10). O’Kelly (2017) suggested that the properties of fibrous peat depend on the fibre content, but we suggest that these Irish blanket peats cannot be considered to be 'fibrous' in the same sense, since even the acrotelm layer may contain relatively few identifiable fibres. The issue is in any case unclear. Previous studies have found that higher fractions of coarse fibres had no effect on measured strength compared with lower coarse fibre contents (Zhang and O’Kelly 2014; Hendy et al. 2014); Price et al. (2005) found that fibre content was not related to compressibility, and Lee et al. (2015) concluded that the effect of fibre orientation on frictional shearing resistance was not clear. However, Boylan and Long (2010) undertook a quantitative analysis of fibre contents adjacent to peat slides in Co. Wicklow and found lower fibre contents with depth. We therefore conclude that the occurrence of failure in upland Irish blanket bogs must be at least in part due to the lower

We found some relationships between measured properties of the peat we analysed. The very strong 631 association $(|r|>0.95)$ between the humus fraction, coarse fibre fraction and total fibre content at the three 632 landslides mean that only one of these parameters may be needed to investigate other properties of peat. This association can be explained by the fact that with increasing plant decomposition, the size and amount of organic particles decrease, resulting in low fibre contents (Fig. 12A). When the fibre content decreases, the water content also decreases (Fig. 12C) because the voids within the fibres, which contain the largest amount 
of water (MacFarlane and Radforth 1968), also decrease. The coarse fibres influence peat structure and possibly strength (see above) and may be used for stability assessments given that at all three sites they were similarly abundant and showed high ( $|\mathrm{r}|>0$.9) correlations with other properties. However, the apparent uniformity of the peat across these sites precludes any suggestion that this may form the basis of a generalised approach, in the absence of further studies from different peatlands (e.g. Northern England or 641 Scotland). Figs. 12D and 12E merely highlights the effect of humification in that if there are more fibres remaining then there should also be more macrofossils that have not yet decomposed too far to be identified. Fig. 12F shows that whichever method of strength determination is used (excluding the field vane), the (shear) strength of the basal peat appears to be around $2 \mathrm{kPa}$. This is consistent with stability analyses of landslides involving failure within the peat (i.e. bog slides, bogflows and some peat flows sensu Dykes and Warburton 2007b) as reported by Dykes (2008c), Dykes and Jennings (2011) and Farrell (2012) and with test results obtained from other similar studies in Ireland (e.g. Dykes 2008c; Dykes et al. 2008).

Two of the characteristics identified as being slightly different at Slieve Anierin, i.e. the monocot content and the coarse fibre content, can be readily determined from small auger samples because they are quantified with respect to the dry mass. A hand auger capable of cutting 'intact' core samples, notwithstanding issues of sample deformation due to compression or fibres not being cut cleanly (Long and Boylan 2013; Hendy et al. 2014), could in principle provide samples for simple determination of dry bulk density and possibly saturated hydraulic conductivity, i.e. the other two slightly distinctive characteristics. However, given that the measured strengths at this site were no different from the others, we cannot say whether measurement of those characteristics would be useful for peats formed from significantly different plant assemblages. It is not possible to generalise any implications of our results for peatlands in general, and notwithstanding previous comments we cannot assume that any of our correlations between botanical and geotechnical characteristics will apply throughout Ireland. There is thus a clear necessity for comprehensive laboratory testing of peat 660 from the site of any proposed development, probably requiring excavation of trial pits for the extraction of 661 appropriate undisturbed samples. However, general recommendations for the most appropriate tests - and testing procedures suitable for peat - will probably take some time to emerge from ongoing research programmes. 
Finally, the very low shear strength indicated above demands some consideration with respect to water conditions within the peat. Blanket bogs in the British Isles may experience water table variations of up to 0.5-1.0 m, but these are occasional reductions below the surface during warm periods of summer weather (Evans et al. 1999; Holden and Burt 2003). The usual condition for these deposits is to be fully saturated to the surface, i.e. with normal effective stress $\approx 0$ and maximum pore water pressure most of the time. Periods of summer drying may increase the normal effective stress by a few $\mathrm{kPa}$ due to the reduced pore water pressure, i.e. temporarily increasing the effective shear strength. Failure within the peat cannot, therefore, be the result of raised pore water pressures throughout the peat matrix due to heavy rainfall (although it could due to external loading). The hydraulic effects of water-filled pipes, cracks and other voids (e.g. Dykes, this volume - in review) may play significant roles in the initiation of failure, i.e. peat mass effects, are thought to be more important than simply the peat matrix (shear) strength, but much more research is needed to test this hypothesis.

\section{Conclusions and Future Work}

The upland blanket bogs of northwestern Ireland appear to be formed from essentially the same assemblages of plant species, dominated by sedges (mostly represented by Eriophorum vaginatum), and therefore having similar physical and botanical characteristics. The data describing those characteristics show a statistically distinct basal layer around $150 \mathrm{~mm}$ thick characterised by, in particular, a sharp reduction in the coarse - and total - fibre content. Tensile strength, experimental low stress direct shear and unconsolidated undrained triaxial compression measurements of peat strength converge on a value of around $2 \mathrm{kPa}$ which is consistent with stability back-analyses requiring undrained shear strengths of around $2 \mathrm{kPa}$ for FS $=1.0$. Contrary to some published accounts, it appears that the lack of coarse fibres may be a contributory factor in the incidence of peat slope failures. Some relationships between measured properties suggest that there may be usable indicators of peat strength and stability conditions, possibly obtainable by means of samples from hand augers, but the apparent uniformity of the peat at these three locations precludes any definitive proposal of useful new methodologies at present. 
693

694

695

696

697

698

699

700

701

702

703

704

705

706

707

708

709

710

711

712

713

714

715

716

717

718

719

720

721

It has been recognised for some time that the development of methods for reliably estimating the shear strength of peat is likely to require some detailed investigations of botanical controls on relevant geotechnical properties (e.g. Dykes 2008a). More recently, O’Kelly (2017, p.21) stated that: ‘More extensive testing of peats with different botanical compositions is recommended to confirm relationships between tensile strength, other strength parameters and humification level'. All of these issues are now starting to be addressed more systematically by a few researchers in several countries. However, more extensive integrative research is needed, perhaps involving palaeoecologists alongside geotechnical engineers, to explore the causes and geotechnical effects of different peat accumulation scenarios. Detailed measurements of all possible characteristics, such as presented in this study, are required for several known sites of peat landslides in each of several different biogeographical zones such as Dartmoor (SW England), North Pennines (N England), Isle of Skye (W Scotland), Shetland Islands (N Scotland), ideally including full depth variations at each study location in order to generate sufficient data for reliable statistical analyses.

\section{Acknowledgements}

This work was funded by Kingston University’s Centre for Earth and Environmental Science Research (CEESR) studentship support fund. EF thanks Prof M Waller (Kingston University), Dr P Hughes (University of Southampton) and Dr M Grant (Kingston University/Wessex Archaeology) for advice and assistance with palaeoecological research techniques. We are grateful to Prof E Bromhead for redrawing Figure 4, and to Mr C Somerfield for assistance with the triaxial testing.

\section{References}

Aaby B and Tauber H (1974) Rates of peat formation in relation to degree of humification and local environment as shown by studies of a raised bog in Denmark. Boreas (Oslo) 4(1), 1-18.

Andrejko MJ, Fiene F and Cohen AD (1983) Comparison of ashing techniques for determination of the inorganic content of peats. In Testing of Peats and Organic Soils (Jarrett PM (ed)). ASTM Special Technical Publication, 820. American Society for Testing and Materials, Philadelphia, pp.5-20.

ASTM (2008) D1997-91: Standard test method for laboratory determination of the fiber content of peat samples by dry mass. American Society for Testing and Materials, Philadelphia. 
Barber KE, Chambers FM, Maddy D, Stoneman R and Brew JS (1994) A sensitive high resolution record of late Holocene climatic change from a raised bog in northern England. The Holocene 4, 198-205.

Blackford JJ and Chambers FM (1993) Determining the degree of peat decomposition for peat based palaeoclimatic studies. International Peat Journal 5, 7-24.

Boylan N and Long M (2010) An investigation of two peat slope failures in the Wicklow mountains. Biology and Environment: Proceedings of the Royal Irish Academy 110B (3), 173-184.

Carlsten P (1993) Peat - Geotechnical Properties and Up-to-Date Methods of Design and Construction. State-of-the-ArtReport. Linköping: Swedish Geotechnical Institute.

Chambers FM, Barber KE, Maddy D and Brew JS (1997) A 5500-year proxy-climate and vegetation record from blanket mire at Talla Moss, borders, Scotland. The Holocene 7, 391-399.

Charman DJ (2002) Peatlands and Environmental Change. Wiley, Chichester.

Crofton HT (1902) How Chat Moss broke out in 1526. Transactions of the Lancashire and Cheshire Antiquarian Society XX, 139-144.

Daniels RE and Eddy A (1990) Handbook of European Sphagna. Institute of Terrestrial Ecology, Natural Environment Research Council. HMSO, London.

Dykes AP (2008a) Properties of peat relating to instability of blanket bogs. In Landslides and Engineered Slopes, Volume 1 (Chen ZY, Zhang J, Li Z, Wu A and Ho K (eds)). Taylor and Francis, London, UK, pp.339-345.

Dykes AP (2008b) Geomorphological maps of Irish peat landslides created using hand-held GPS. Journal of Maps v2008, 258-276.

Dykes AP (2008c) Tensile strength of peat: laboratory measurement and role in Irish blanket bog failures. Landslides 5(4), 417-429.

Dykes AP (2009) Geomorphological maps of Irish peat landslides created using hand-held GPS - Second Edition. Journal of Maps v2009, 179-185.

Dykes AP (this issue? - still being revised) New insights from a recent peat slide at Croaghan, Co. Antrim, Northern Ireland.

Dykes AP and Jennings P (2011) Peat slope failures and other mass movements in western Ireland, August 2008. Quarterly Journal of Engineering Geology and Hydrogeology 44(1), 5-16.

Dykes AP and Kirk KJ (2001) Initiation of a multiple peat slide on Cuilcagh Mountain, Northern Ireland. Earth Surface Processes and Landforms 26, 395-408.

Dykes AP and Warburton J (2007a) Significance of geomorphological and subsurface drainage controls on failures of peat-covered hillslopes triggered by extreme rainfall. Earth Surface Processes and Landforms 32, 1841-1862. 
Dykes AP and Warburton J (2007b) Mass movements in peat: A formal classification scheme. Geomorphology 86(1-2), 73-93.

Dykes AP and Warburton J (2008a) Failure of peat-covered hillslopes at Dooncarton Mountain, Co. mayo, Ireland: Analysis of topographic and geotechnical factors. Catena 72, 129-145.

Dykes AP and Warburton J (2008b) Characteristics of the Shetland Islands (UK) peat slides of 19 September 2003. Landslides 5, 213-226.

Dykes AP, Gunn J and Convery (Née Kirk) KJ (2008) Landslides in blanket peat on Cuilcagh Mountain, northwest Ireland. Geomorphology 102, 325-340.

Evans MG, Burt TP, Holden J, Adamson JK (1999) Runoff generation and water table fluctuations in blanket peat: evidence from UK data spanning the dry summer of 1995. Journal of Hydrology 221, 141-160.

Farrell ER (2012) Organics/peat soils. In ICE Manual of Geotechnical Engineering: Volume 1, Geotechnical Engineering Principles, Problematic Soils and Site Investigation (Burland J, Chapman T, Skinner H and Brown M (eds)). ICE Publishing, London, UK, pp.463-479.

Foteu Madio ES (2013) Botanical and geotechnical influences on peat instability. Unpublished PhD thesis, Kingston University, UK.

Foteu Madio ES, Dykes AP, Waller MP, Hughes P and Grant MJ (2012) Botanical and geotechnical influences on peat instability. In Landslides and Engineered Slopes: Protecting Society through Improved Understanding (Vol. 2) (Eberhardt E, Froese C, Turner AK and Leroueil S (eds)). Proceedings of the 11th International and 2nd North American Symposium on Landslides and Engineered Slopes. CRC Press, London, pp.421-427.

Gilman K, Newson MD (1980) Soil Pipes and Pipeflow: a Hydrological Study in Upland Wales, British Geomorphological Research Group Monograph 1. Geobooks: Norwich.

Grosse-Brauckmann G (1972) Über pflanzliche Makrofossilien mitteleuropäischer Torfe - I. Gewebereste krautiger Pflanzen und ihre Merkmale. Telma2, 19-55.

Hammond RF (1979) The Peatlands of Ireland. Survey Bulletin No. 35. An Foras Talúntais, Dublin

Hanrahan ET (1954) An investigation of some physical properties of peat. Géotechnique 4, 108-123.

Head KH (1994) Manual of Soil Laboratory Testing, Permeability, Shear Strength and Compressibility Testing. Volume 2. Wiley, New York.

Helenelund KV (1967) Vane tests and tension tests on fibrous peat. Proceedings of the Geotechnical Conference, Oslo, Vol. 1, 199-203.

Hendy MT, Barbour SL and Martin CD (2014) Evaluating the effect of fiber reinforcement on the anisotropic undrained stiffness and strength of peat. Journal of Geotechnical and Geoenvironmental Engineering, published on-line at doi:10.1061/(ASCE)GT.1943-5606.0001154. 
Hobbs NB (1986) Mire morphology and the properties and behaviour of some British and foreign peats. Quarterly Journal of Engineering Geology 19, 7-80.

Holden J, Burt TP (2003) Hydrological studies on blanket peat: the significance of the acrotelm-catotelm model. Journal of Ecology 91: 103-113.

IUGS - International Union of Geological Sciences Working Group on Landslides (1995) A suggested method for describing the rate of movement of landslides. Bulletin International Association of Engineering Geology 52, 75-78.

Jarrett PM (1983) Summary. In Testing of Peats and Organic Soils (Jarrett PM (ed)). ASTM Special Technical Publication, 820. American Society for Testing and Materials, Philadelphia, pp.233-237.

Katz NJ, Katz SV and Skobeyeva EI (1977) Atlas of plant remains in peat soil. Nedra [In Russian].

Kirk KJ (2001) Instability of blanket bog slopes on Cuilcagh Mountain, N.W. Ireland. Unpublished PhD thesis. University of Huddersfield, UK.

Klute A, Dirksen C (1986) Hydraulic conductivity and diffusivity: laboratory methods. Methods of Soil Analysis Part 1. Physical and Mineralogical Methods. Agronomy Monograph (2nd edition), Vol. 9. Soil Science Society of America, Madison, pp. 687- 734.

Landva AO and Pheeney PE (1980) Peat fabric and structure. Canadian Geotechnical Journal 17(3), 416-435.

Lee J-S, Seo S-Y and Lee C (2015) Geotechnical and geophysical characteristics of muskeg samples from Alberta,

Lindsay R, Bragg O (2005) Wind farms and blanket peat: a report on the Derrybrien bog slide (2nd edition). Derrybrien Development Cooperative Ltd., Gort.

Long M (2005) Review of peat strength, peat characterisation and constitutive modelling of peat with reference to landslides. Studia Geotechnica et Mechanica XXVII, 67-90.

Long M and Boylan N (2013) Predictions of settlement in peat soils. Quarterly Journal of Engineering Geology and Hydrogeology 46, 303-322.

Long M and Jennings P (2006) Analysis of the peat slide at Pollatomish, County Mayo, Ireland. Landslides 3(1), 51-61.

812 Mills AJ (2002) Peat slides: morphology, mechanisms and recovery. Unpubl. PhD thesis. University of Durham, UK.

813 Moore PD (1984) The classification of mires: An introduction. In European Mires (Moore PD (ed)). Academic Press, 814 London, pp.1-10.

815 O’Kelly BC (2014) Drying temperature and water content-strength correlations. Environmental Geotechnics 1 (EG2), 81-95. 
O’Kelly BC (2017) Measurement, interpretation and recommended use of laboratory strength properties of fibrous peat. Geotechnical Research, published on-line at http://dx.doi.org/10.1680/jgere.17.00006.

Price JS, Cagampan J and Kellner E (2005) Assessment of peat compressibility: is there an easy way? Hydrological Processes 19, 3469-3475.

821 Skempton AW and Petley DN (1970) Ignition loss and other properties of peats and clays from Avonmouth, Kings Lynn and Cranberry Moss. Geotechnique 20(4), 343-356.

Smith AJE (2004) The moss flora of Britain and Ireland (2nd edition). Cambridge University Press, Cambridge.

Troels-Smith J (1955) Karakterisering af lose jordater (Characterisation of unconsolidated sediments). Denmarks Geologiske Undersogelse 4(3), 1-73.

von Post L (1922) Sveriges geologiska undersoknings torvinventering och nagre av dess hittills vunna resultat, sr. mosskulturfor. Tidskr 1, 1-27.

Walker D and Walker PM (1961) Stratigraphic evidence of regeneration in some Irish bogs. Journal of Ecology 49, 169-185.

830 Warburton J, Higgit D and Mills A (2003) Anatomy of a Pennine peat slide, northern England. Earth Surface Processes and Landforms 28(5), 457-473.

Warburton J, Holden J and Mills AJ (2004) Hydrological controls of superficial mass movements in peat. Earth-Science Reviews 67(1-2), 139-156.

834 Yang J and Dykes AP (2006) The liquid limit of peat and its application to the understanding of Irish blanket bog failures. Landslides 3(3), 205-216.

836 Zhang L and O’Kelly BC 2014 The principle of effective stress and triaxial compression testing of peat. Geotechnical 
Figure 1. Location of the study area in northwest Ireland, showing the distribution of peatlands (after Hammond 1979). The outlined rectangle is enlarged to show the locations of the three bogflows: (left to right) ST = Straduff Townland, SA = Slieve Anierin, SR = Slieve Rushen. Modified from Yang and Dykes (2006).

Figure 2. General views of the three study areas. (A) Straduff Townland bogflow, looking downslope from above the head (July 2010). (B) Slieve Rushen bogflow, looking across at the failed slope from the other side of the peat basin into which its displaced peat flowed (July 2010). (C) Slieve Anierin bogflow from the air (Nov. 1998, photo by APD).

Figure 3. Measuring the tensile strength of the peat: (A) the two sets of steel 'fingers' that are pushed through the centre of a cut block of undisturbed peat $100 \mathrm{~mm}$ high $\times 100 \mathrm{~mm}$ wide and 40-60 mm thick; (B) one half of a sample following tensile failure, still adhering to one set of 'fingers'; (C) the testing apparatus, showing: centre the 'fingers' assembly installed (without a sample); right - the force proving ring; lower far left - the hanger for applying the weights that apply the load just visible beside the end of the cupboards. Details of the design and development of this apparatus are provided in Dykes (2008c).

Figure 4. Peat stratigraphy across the slope above the head of the Slieve Rushen bogflow. This linear transect was located 7.5 m upslope of the source area head at the closest point. Modified from Foteu Madio (2013).

Figure 5. Results of macrofossil analyses of samples obtained from across the Slieve Rushen bogflow. Labels A1, A5, etc. refer to sampling positions: A1 to A9 are shown in Fig. 5; E1/E3 and E4/E7 are located either side of the downslope extent of the source area. The materials found at each position are from, and in the same order as, this list: Charcoal (0.5-1 mm); Charcoal (less than $0.5 \mathrm{~mm}$ ); Ericales; Eriophorum vaginatum; Monocot fragments (Monocot leaves at E4), Roots; Sphagnum; Unidentified organic matter. Source: Foteu Madio (2013).

Figure 9. 'Raw’ percentage of light transmission at the Straduff Townland bogflow (ST).

Figure 10. Depth variations of fibre contents throughout the lower half of the peat profile at each landslide: (A) Straduff Townland, (B) Slieve Rushen, (C) Slieve Anierin. Source: Foteu Madio (2013).

Figure 11. Macrofossil content of the peat monolith from the three landslides: (a) ST, (b) SR, (c) SA. Parameter values are raw counts for charcoal and E. vaginatum spindles, otherwise percentages. The figure shows the dendrogram produced from unconstrained incremental sum square cluster analysis of strata analysed. Dashed lines separate clusters corresponding to zones in the diagram. Source: Foteu Madio (2013). 
903

Figure 12. Correlations between physical/geotechnical parameters and between botanical characteristics of the peat. (A) Total fibre content vs. humus fraction. (B) Total fibre content vs. coarse fibre fraction. (C) Coarse fibre fraction vs. field water content. (D) Monocot fragments vs. total fibre content. (E) Unidentified organic matter vs. von Post humification. (F) Undrained shear strength (including 'field vane strength') vs. total fibre content. In (A) to (E), solid line $=$ ST, long dashed line $=$ SR and the thin broken line $=$ SA. After Foteu Madio (2013).

Figure 13.Variation of mean thickness of basal peat depths according to specific physical properties at all three landslides.
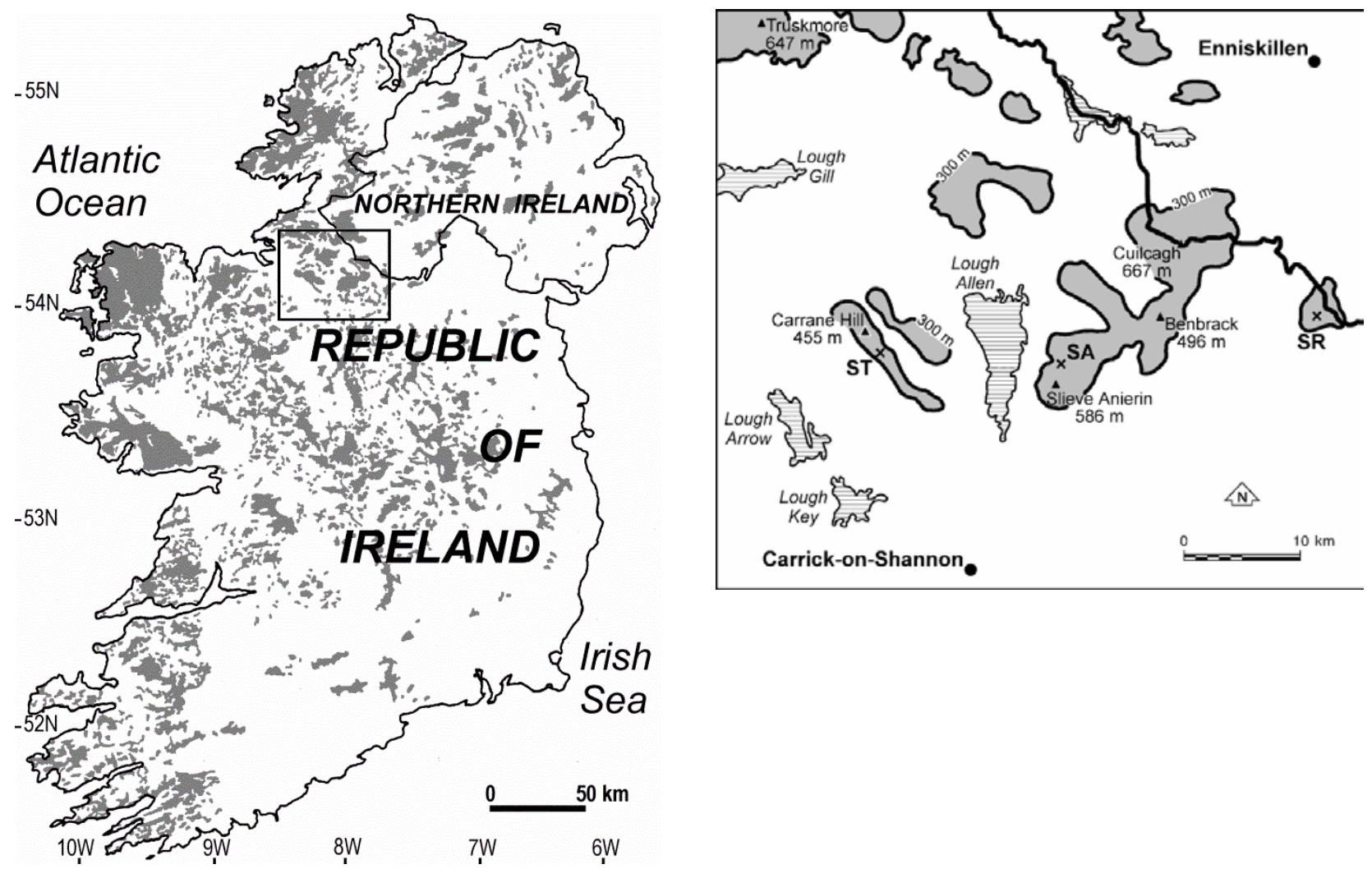

Figure 1. Location of the study area in northwest Ireland, showing the distribution of peatlands (grey shading, after Hammond 1979). The outlined rectangle is enlarged, right, to show the relative locations of the three bogflows and their upland contexts: (left to right) ST = Straduff Townland, SA = Slieve Anierin, SR = Slieve Rushen. In this study area map, grey shading is land above 300 m elevation, horizontal stripes indicate water bodies and the solid black line is the international border. Modified from Yang and Dykes (2006). 

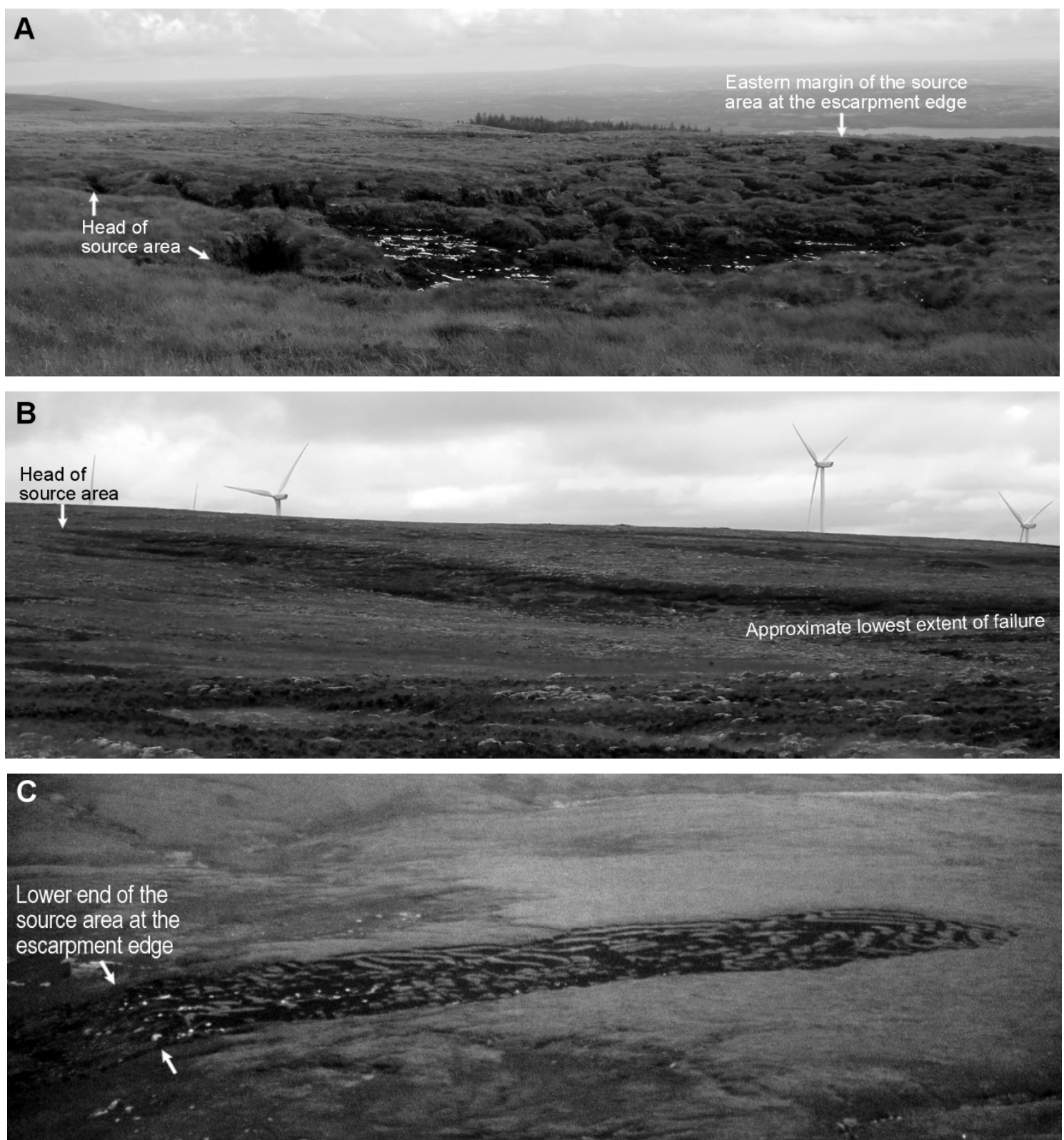

915 Figure 2. General views of the three study areas. (A) Straduff Townland bogflow, looking downslope from above the 916 head (July 2010). (B) Slieve Rushen bogflow, looking across at the failed slope from the other side of the peat basin 917 into which its displaced peat flowed (July 2010). (C) Slieve Anierin bogflow from the air (Nov. 1998, photo by APD). 

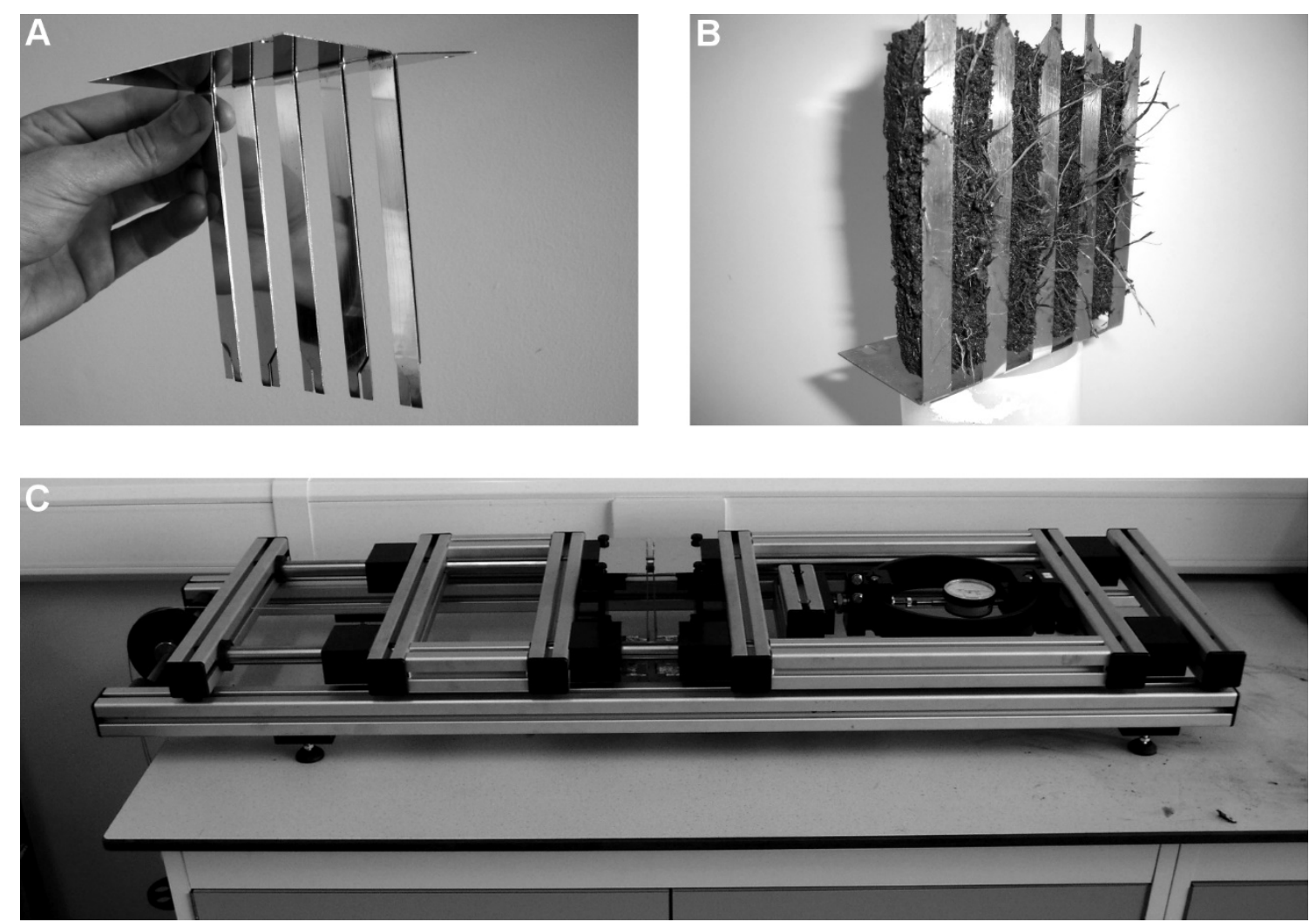

Figure 3. Measuring the tensile strength of the peat: (A) the two sets of steel 'fingers' that are pushed through the centre of a cut block of undisturbed peat $100 \mathrm{~mm}$ high $\times 100 \mathrm{~mm}$ wide and 40-60 mm thick; (B) one half of a sample following tensile failure, still adhering to one set of 'fingers'; (C) the testing apparatus, showing: centre - the 'fingers' assembly installed (without a sample); right - the force proving ring; lower far left - the hanger for applying the weights that apply the load just visible beside the end of the cupboards. Details of the design and development of this apparatus are provided in Dykes (2008c).

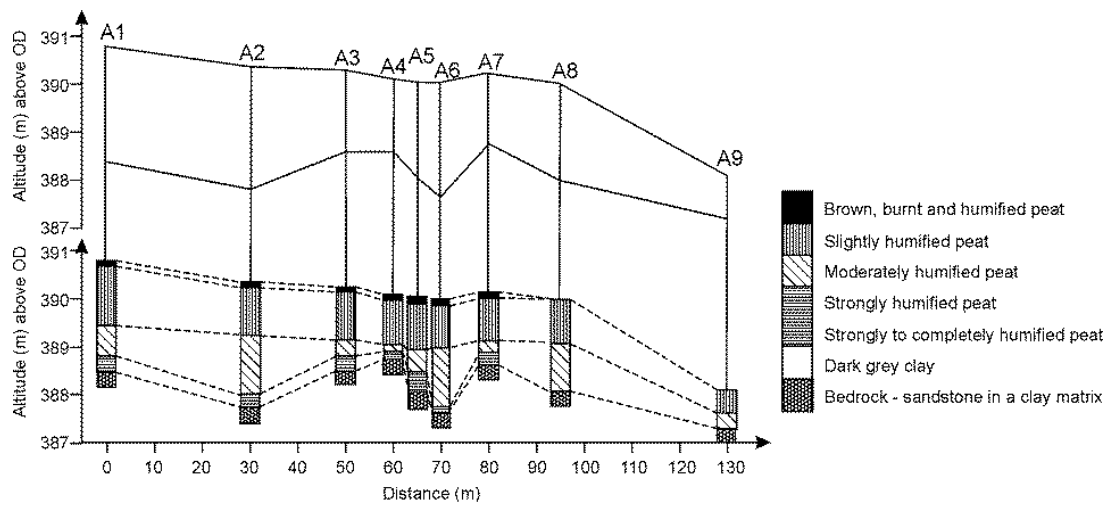

Figure 4. Peat stratigraphy across the slope above the head of the Slieve Rushen bogflow. This linear transect was located $7.5 \mathrm{~m}$ upslope of the source area head at the closest point. Modified from Foteu Madio (2013). 


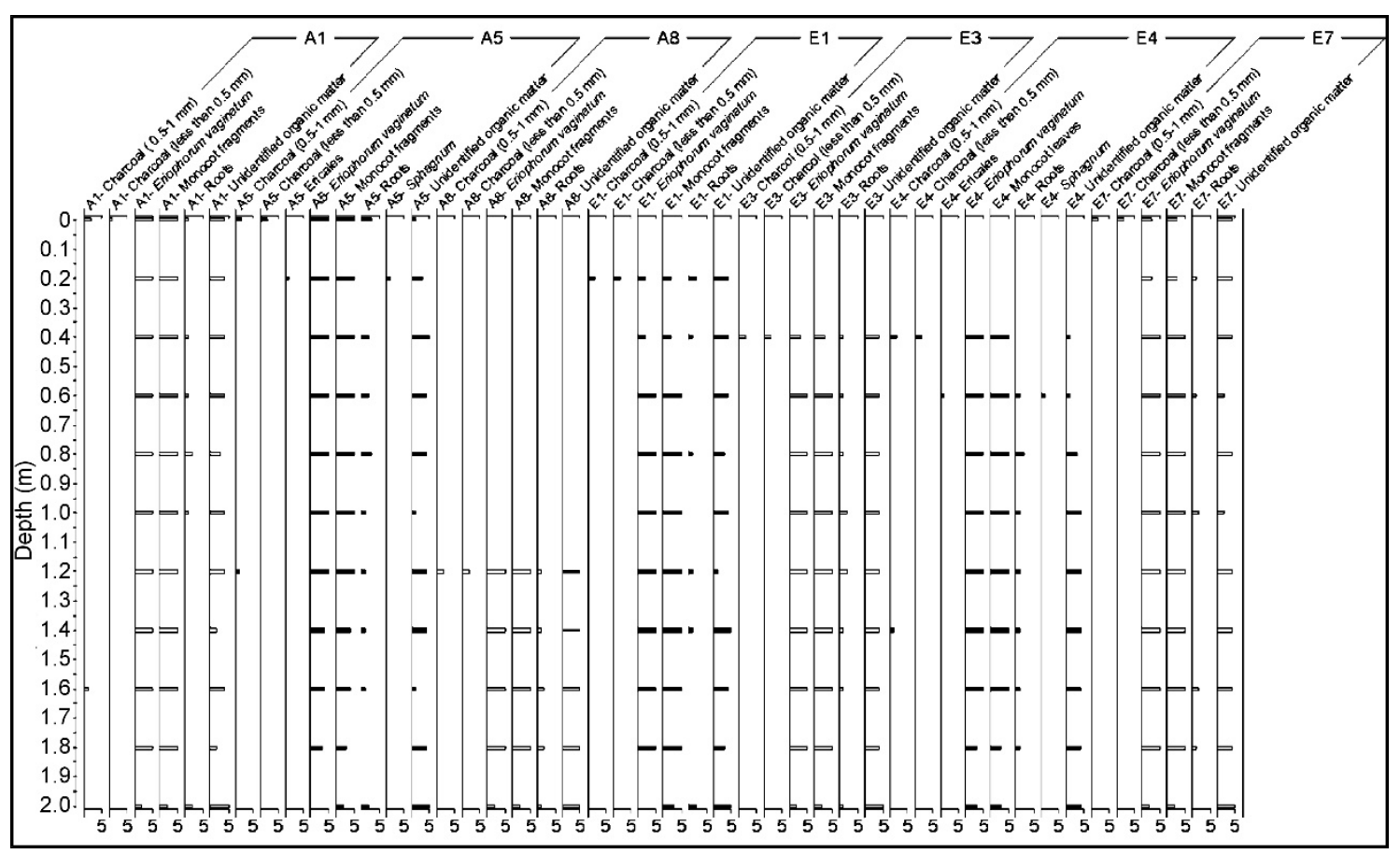

Figure 5. Results of macrofossil analyses of samples obtained from across the Slieve Rushen bogflow. Labels A1, A5, etc. refer to sampling positions: A1 to A9 are shown in Fig. 5; E1/E3 and E4/E7 are located either side of the downslope extent of the source area. The materials found at each position are from, and in the same order as, this list: Charcoal (0.5-1 mm); Charcoal (less than $0.5 \mathrm{~mm}$ ); Ericales; Eriophorum vaginatum; Monocot fragments (Monocot leaves at E4), Roots; Sphagnum; Unidentified organic matter. Source: Foteu Madio (2013). 

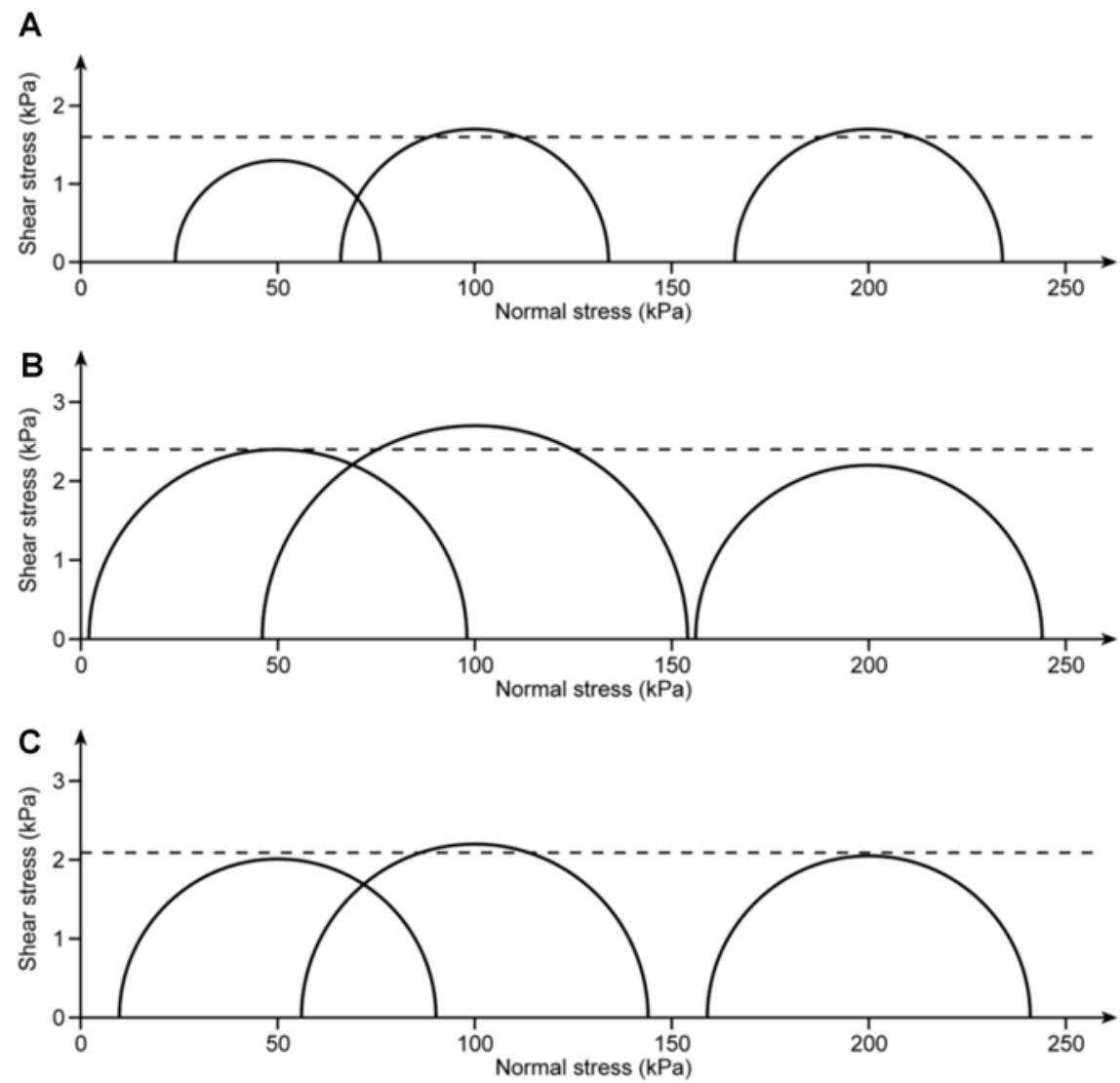

Figure 7. Mohr's Circles obtained from unconsolidated-undrained triaxial tests on peat samples from the three

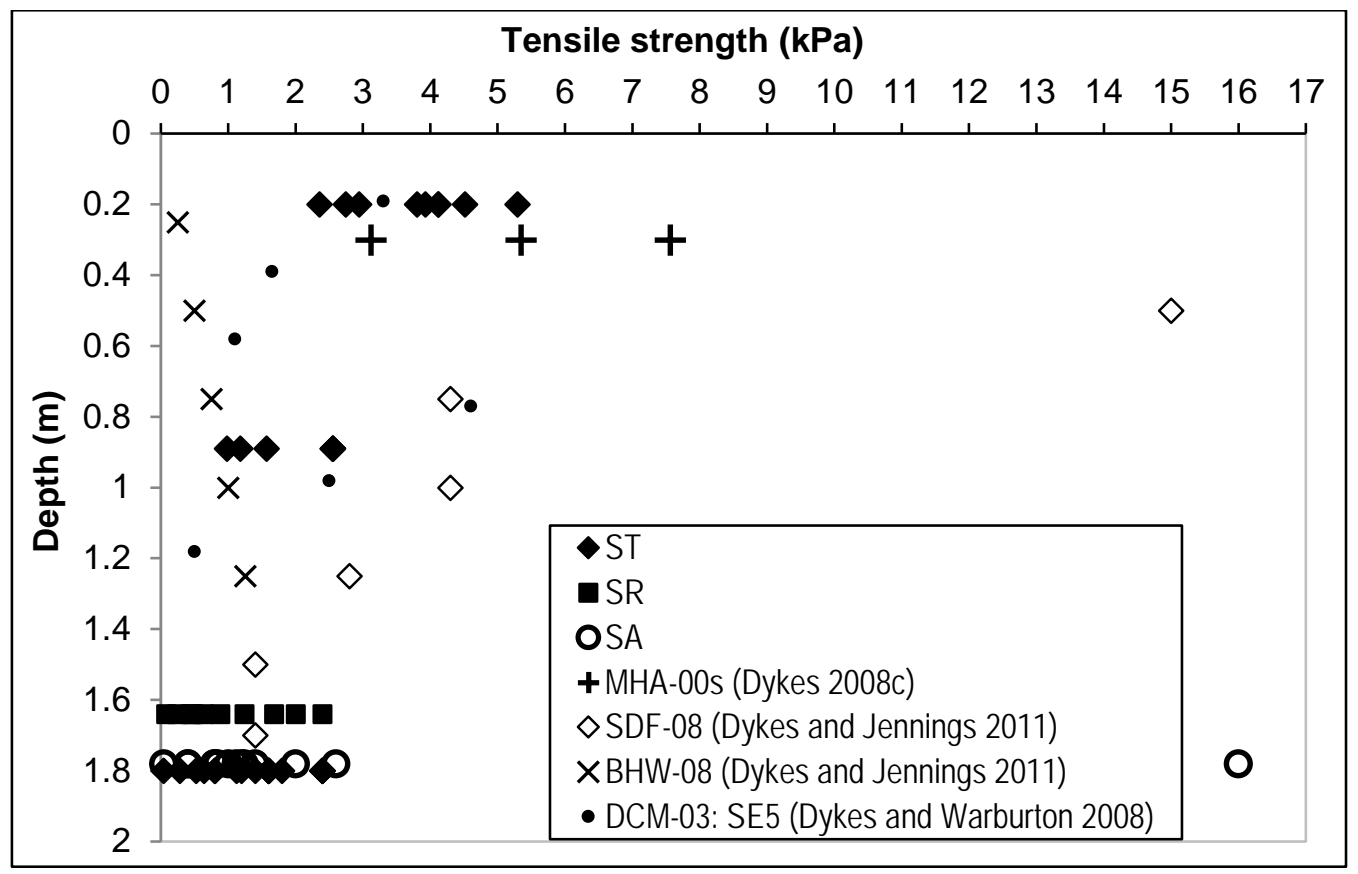

Figure 8. Tensile strength results obtained from the three landslides in this study and from previous studies using the same methodology. MHA-00s refers to the Maghera bogflow, Co. Galway; SDF-08 is bogflow ST in this study; BHW08 is the Ballincollig Hill peat flow, Co. Kerry; DCM-03 is the collective reference for the 40 landslides that occurred on Dooncarton Mountain, Co. Mayo on 19 September 2003, the results here being obtained from peat slide 'SE5'. Modified from Foteu Madio (2013). 


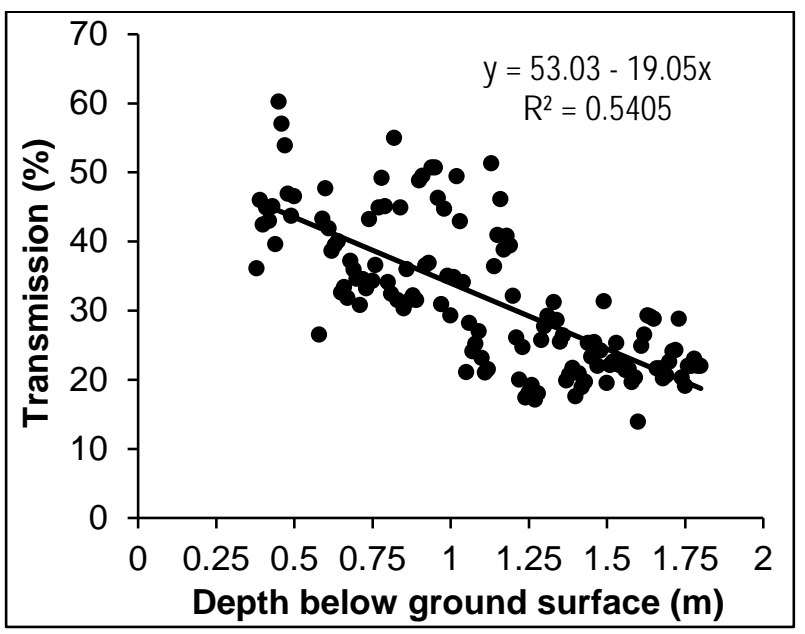

Figure 9. 'Raw' percentage of light transmission at the Straduff Townland bogflow (ST).

969

970

971

972

973

974

975

976

977

978

979

980

981

982

983

984

985

986

987

988

989

990

991 

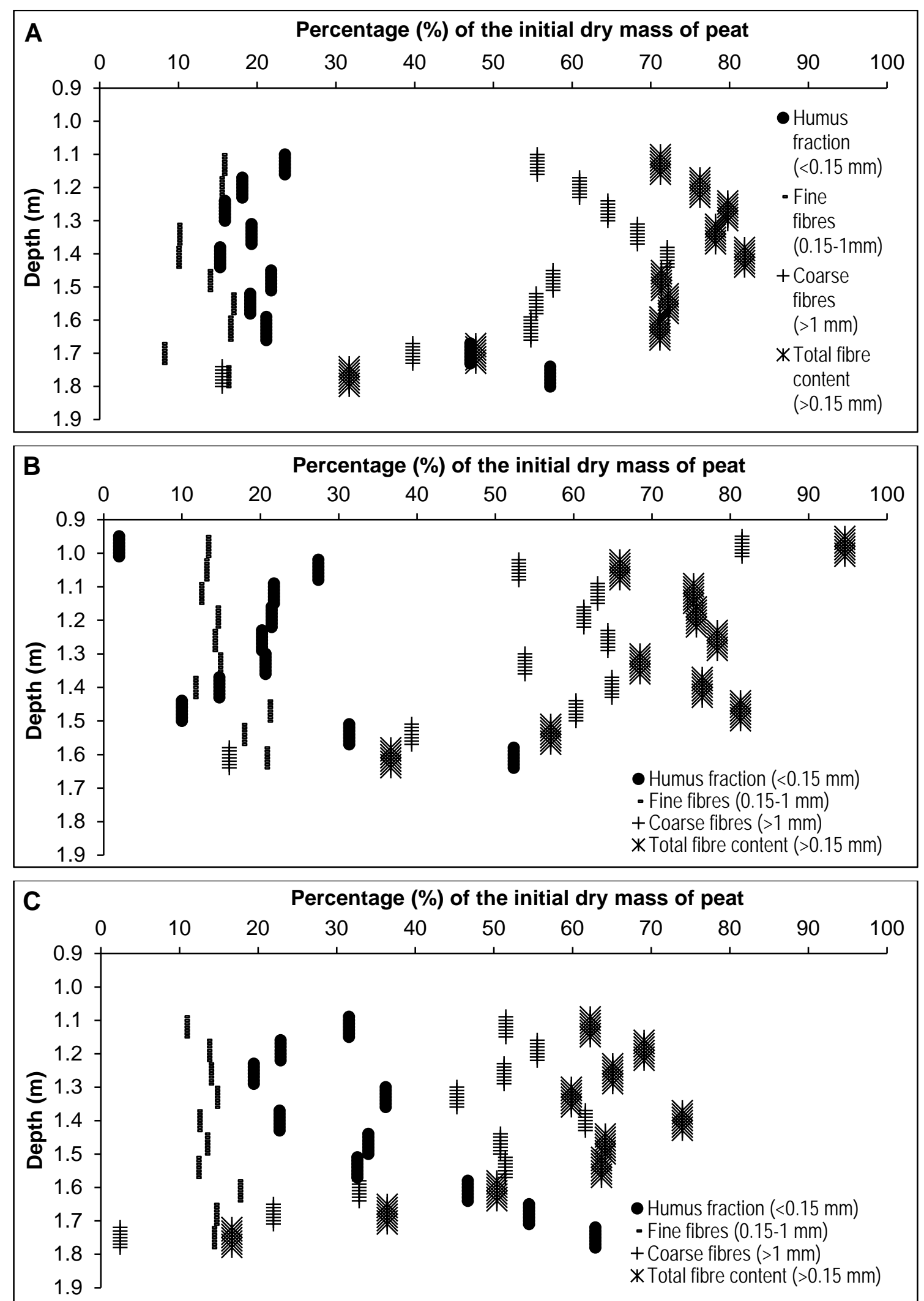

Figure 10. Depth variations of fibre contents throughout the lower half of the peat profile at each landslide: (A) Straduff Townland, (B) Slieve Rushen, (C) Slieve Anierin. Source: Foteu Madio (2013). 

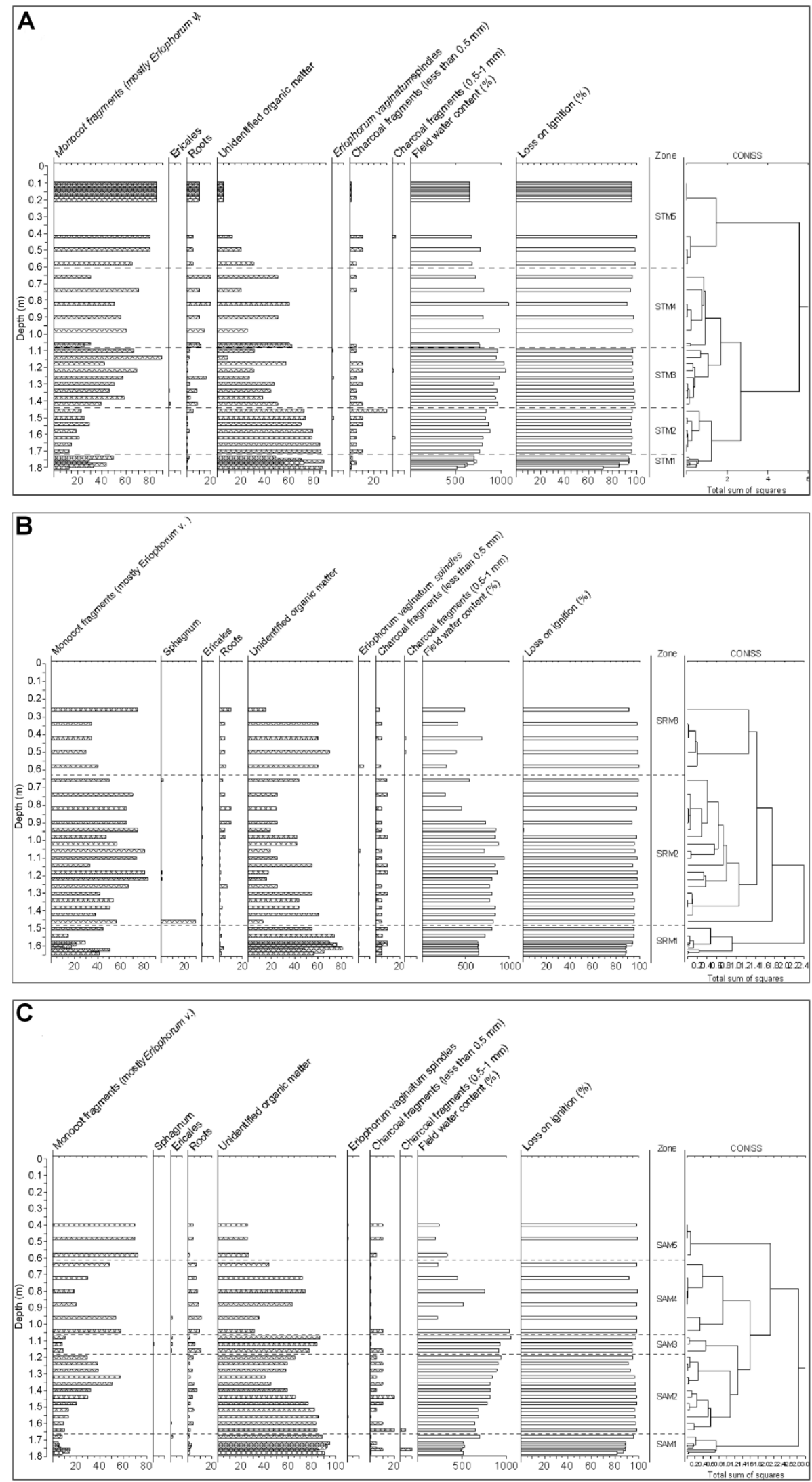

Figure 11. Macrofossil content of the peat monolith from the three landslides: (a) ST, (b) SR, (c) SA. Parameter values are raw counts for charcoal and $E$. vaginatum spindles, otherwise percentages. The figure shows the dendrogram produced from unconstrained incremental sum square cluster analysis of strata analysed. Dashed lines separate clusters corresponding to zones in the diagram. Source: Foteu Madio (2013). 
(A)

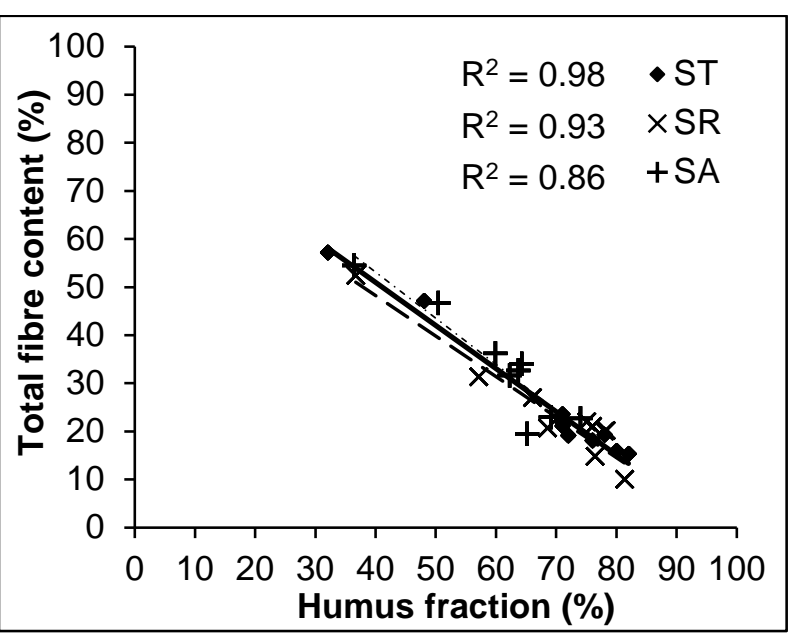

1010

1011

1012

(C)

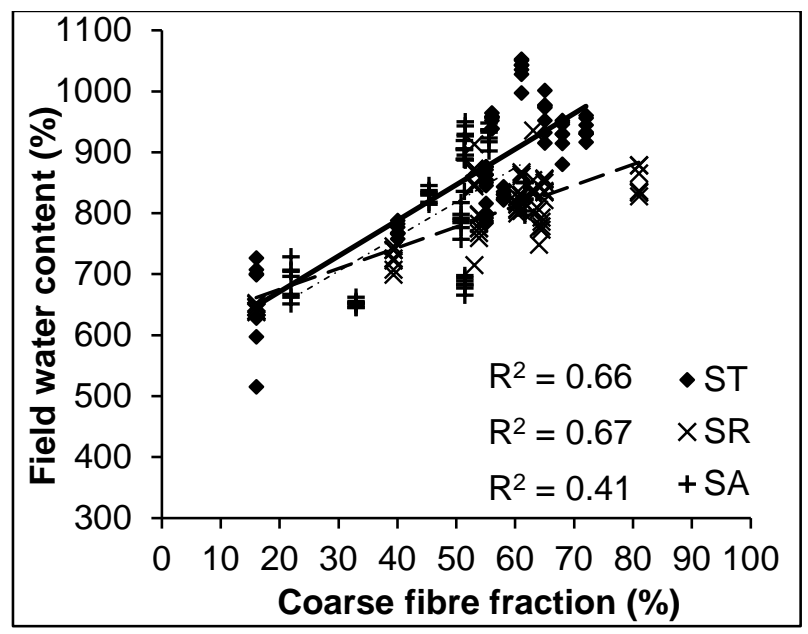

1013 (E)

1014

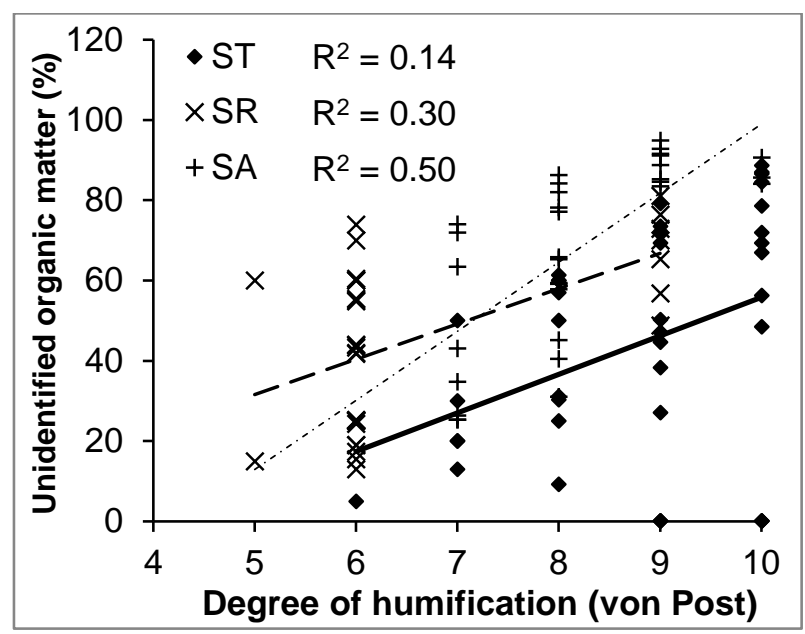

(B)

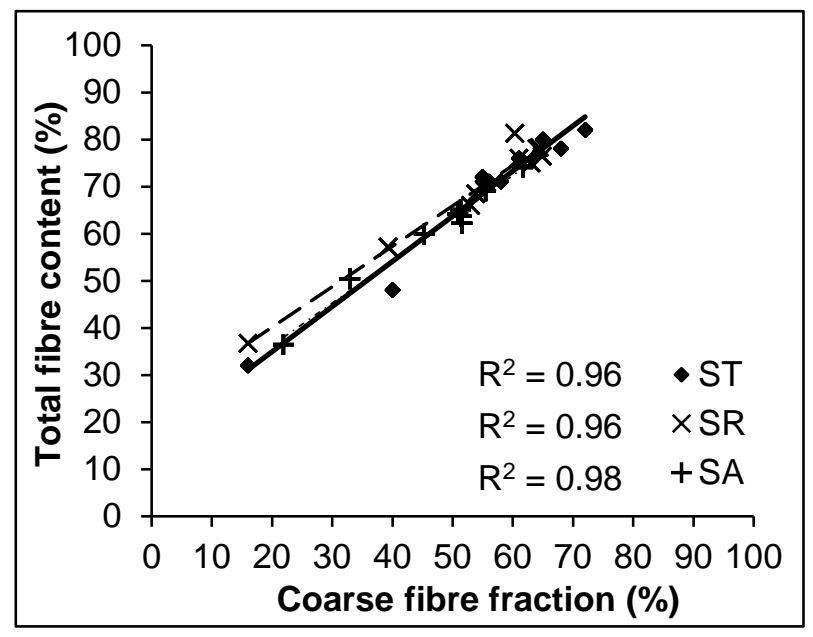

(D)

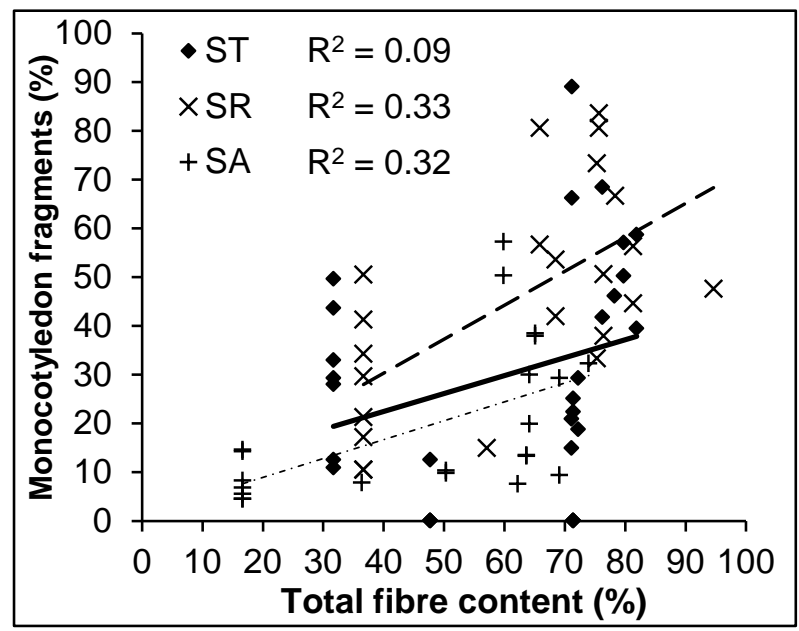

(F)

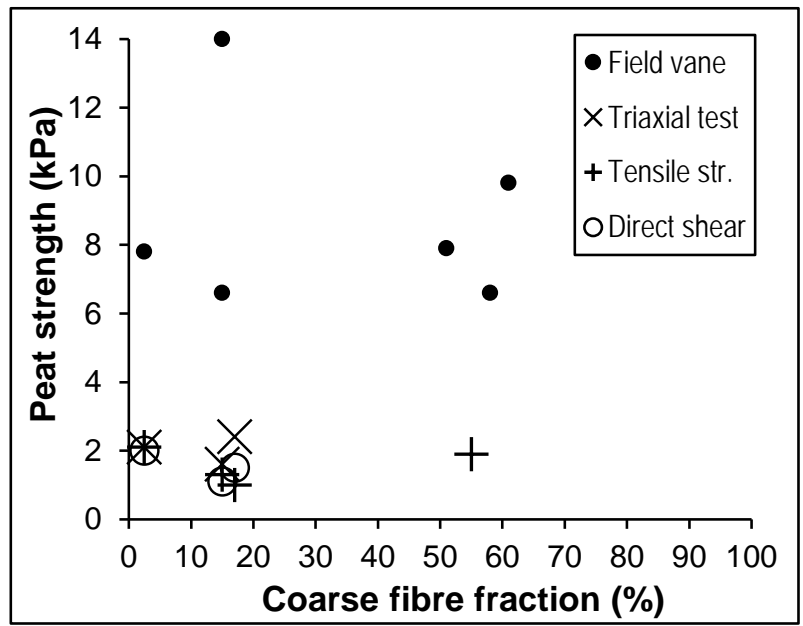

1015

1016

1017

1018

1019

1020

Figure 12. Correlations between physical/geotechnical parameters and between botanical characteristics of the peat. (A) Total fibre content vs. humus fraction. (B) Total fibre content vs. coarse fibre fraction. (C) Coarse fibre fraction vs. field water content. (D) Monocot fragments vs. total fibre content. (E) Unidentified organic matter vs. von Post humification. (F) Undrained shear strength (including 'field vane strength') vs. total fibre content. In (A) to (E), solid line = ST, long dashed line $=$ SR and the thin broken line $=$ SA. After Foteu Madio (2013). 


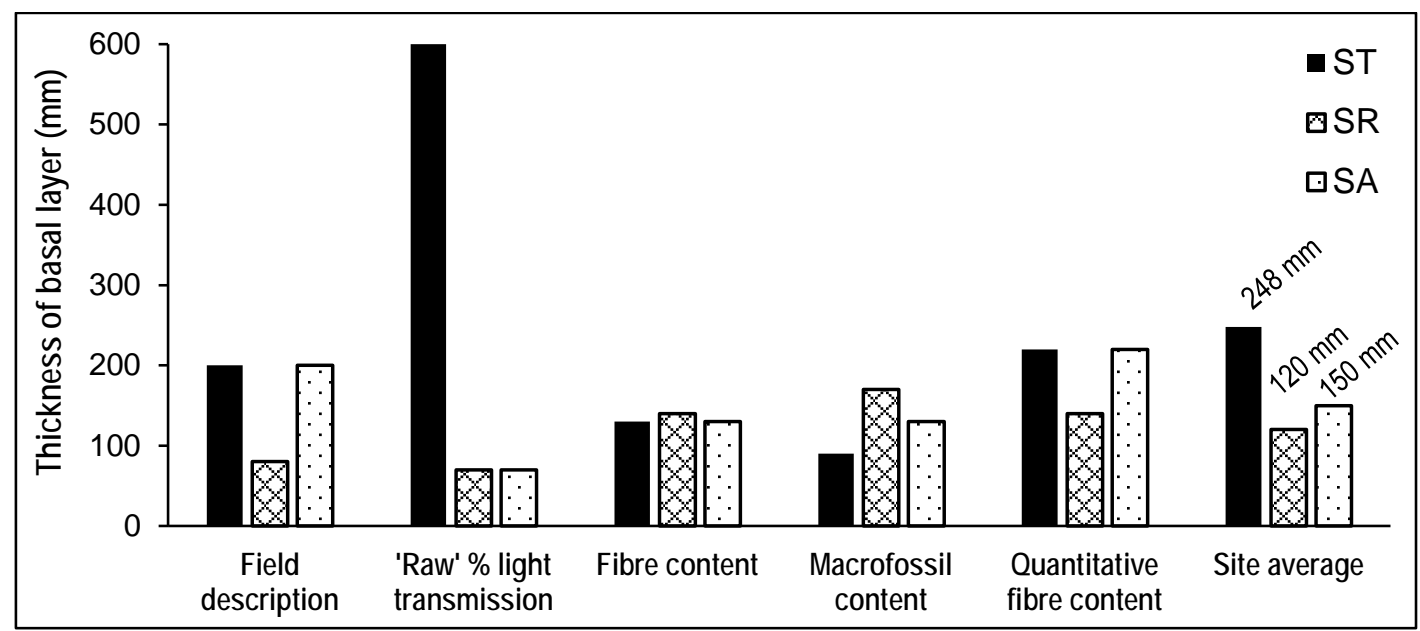

1023 Figure 13. Different estimates of mean thickness of basal peat depths according to specific physical properties at all 1024 three landslides. 